\title{
Testing Geochemical Predictions of Trace Element Toxicity and Bioavailability at a Rehabilitated Mine Site
}

\author{
M. E. Fairgray ${ }^{1}$ (1) J. G. Webster-Brown ${ }^{1} \cdot$ J. Pope $^{2}$
}

Received: 10 April 2019 / Accepted: 31 October 2019 / Published online: 12 November 2019

(c) The Author(s) 2019

\begin{abstract}
The speciation, toxicity and bioavailability of trace elements in mine drainage environments can be readily predicted using geochemical modelling, and this is frequently the basis for assessing the likely impacts of mine effluents and efficacy of rehabilitation plans. However, such predictions are rarely validated against observed trace element characteristics after mine rehabilitation is complete. In this study of a former $\mathrm{Pb}-\mathrm{Zn}$ mine in New Zealand, PHREEQC was used to predict dissolved trace element and sediment-bound speciation for the rehabilitated mine site, and the results were compared to the observed water and sediment quality. For $\mathrm{Fe}, \mathrm{Mn}, \mathrm{Al}, \mathrm{Cu}, \mathrm{Pb}, \mathrm{Zn}, \mathrm{Cd}, \mathrm{Ni}$, As, and $\mathrm{Sb}$, it was predicted that only $\mathrm{Zn}^{2+}$ and $\mathrm{Cd}^{2+}$ concentrations would exceed recommended guideline values for ecosystem health. PHREEQC indicated that the $\mathrm{pH}$ would have to be raised to $>9.5$ to reduce these toxicants to a level fit for ecosystem health. Modelling of potential mineral formation indicated that the waters were saturated with respect to a variety of $\mathrm{Fe}-, \mathrm{Mn}$ - and $\mathrm{Al}$ (oxy)hydroxides at and immediately downstream of the mine site, but were not saturated with respect to any trace element-bearing minerals, or sulfide or carbonate phases. This was consistent with X-ray diffraction and scanning electron microscopy (SEM) observations of the sediment. Sequential extraction of the sediment showed strong associations of $\mathrm{Zn}, \mathrm{Cu}, \mathrm{Pb}$, As and $\mathrm{Sb}$ with iron (oxy) hydroxides. Modelling trace element adsorption onto only hydrous ferric oxide surfaces accurately predicted the adsorption of $\mathrm{Zn}, \mathrm{Cd}, \mathrm{Cu}$, and $\mathrm{Ni}$, but predictions of $\mathrm{Pb}$ and $\mathrm{As}$ adsorption were less reliable. Additionally, a strong association between $\mathrm{Zn}$ and Mn oxyhydroxide was observed in SEM analysis.
\end{abstract}

Keywords Acid mine drainage $\cdot$ Attenuation processes $\cdot$ Metal speciation $\cdot$ Sequential extraction

\section{Introduction}

Mining can have severe impacts on the natural environment in the vicinity of a mineral resource (Bradshaw and Chadwick 1980; Cooke and Johnson 2002), including the contamination of local streams with acidic mine waters (Lottermoser 2003). The oxidation of iron sulfide minerals such as pyrite, pyrrhotite, marcasite, and mackinawite create

Electronic supplementary material The online version of this article (https://doi.org/10.1007/s10230-019-00644-y) contains supplementary material, which is available to authorized users.

M. E. Fairgray

marlese.fairgray@pg.canterbury.ac.nz

1 Waterways Centre for Freshwater Management, University of Canterbury and Lincoln University, Christchurch,

New Zealand

2 CRL Energy, Christchurch, New Zealand acidic conditions in weathering fluids (Lottermoser 2003; Nordstrom and Alpers 1999), which can then facilitate the dissolution of other minerals, releasing trace elements into downstream environments (Ziemkiewicz et al. 1997). The low $\mathrm{pH}$, high sulfate, trace element-rich discharge can be referred to as acid rock drainage (ARD), if occurring naturally, or acid mine drainage (AMD), if associated with mining activities. This distinction is made because iron sulfide oxidation can be accelerated by mining activities when mineral surfaces are exposed to the atmosphere at a faster rate than would occur naturally (Akcil and Koldas 2006; Nordstrom and Alpers 1999). Neutral pH drainage can also occur where there is either low iron sulfide content in the ore or sufficient acid-neutralizing capacity in the host rock (Banks et al. 1997; Blowes et al. 2003; Warrender et al. 2011).

Freshly formed $\mathrm{Fe}-, \mathrm{Mn}$ - and $\mathrm{Al}$ (oxy)hydroxides readily adsorb many trace elements (Johnson and Hallberg 2005; Watzlaf et al. 2004). Under favorable conditions, such (oxy) hydroxides will coagulate and settle into the sediment, 
together with the associated trace elements, reducing the immediate toxicity of the water to aquatic life, but forming a reservoir of trace elements in the stream sediments. Spatial or temporal changes in $\mathrm{pH}$, redox conditions, and water chemistry influence trace element adsorption and mineral precipitation processes. Reduced $\mathrm{pH}$ and redox conditions, for example, can lead to desorption of adsorbed cations or, if significant enough, the dissolution of oxide phases to which these ions had adsorbed. Additionally, $\mathrm{pH}$ and redox conditions when the oxide precipitate is forming can affect how effectively trace elements are scavenged from solution (Dale et al. 2015).

The presence and extent of these processes can be theoretically predicted using geochemical models based on thermodynamic equilibria, providing an indication of expected dissolved trace element speciation and adsorption, mineral precipitation under certain conditions and how this may change if conditions are altered. It is an important tool used in mine remediation planning to determine end points for different remediation techniques and to assess the ongoing toxicity and mobility of trace elements after rehabilitation, without having to carry out expensive and time-consuming field trials. However, there are few instances where geochemical model predictions have been validated against observations at a rehabilitated mine site.

The purpose of this research was therefore to compare geochemically modelled trace element speciation, adsorption, and precipitation to that observed at a rehabilitated former $\mathrm{Pb}-\mathrm{Zn}$ mine. PHREEQC (Parkhurst and Appelo 2013) was used to predict dissolved and sedimentary trace element speciation and trace element attenuation processes, which was then compared to observed trace element associations in the water and sediment of streams draining the mine site. The reliability of this approach for determining the ongoing environmental impacts of a rehabilitated mine site was then assessed.

The mine used in this research was the Tui Mine in New Zealand. The Tui mine is a former base metal mine located on the western slopes of Mt. Te Aroha in the Kaimai Ranges. It is $3 \mathrm{~km}$ northeast of the township of Te Aroha, at the base of the Coromandel Peninsula (Fig. 1). The mine sits at an altitude of between 300 and $400 \mathrm{~m}$ above mean sea level, is surrounded by native bush, and drained by two streams: the Tui Stream on the north side of the mine site and the Tunakohoia Stream on the south side. Both streams are tributaries of the Waihou River. The average rainfall is high, at around $2100 \mathrm{~mm} / \mathrm{year}$ on Mt. Te Aroha (Harvey and Webster-Brown 2003).

The ore extracted at the Tui Mine came from two mineralized quartz reefs containing sphalerite $(\mathrm{ZnS})$, galena $(\mathrm{PbS})$, pyrite $\left(\mathrm{FeS}_{2}\right)$, and chalcopyrite $\left(\mathrm{CuFeS}_{2}\right)$ with minor amounts of cinnabar $(\mathrm{HgS})$, marcasite $\left(\mathrm{FeS}_{2}\right)$, tetrahedrite $\left[(\mathrm{Cu}, \mathrm{Fe})_{12} \mathrm{Sb}_{4} \mathrm{~S}_{13}\right]$, and tennantite $\left[(\mathrm{Cu}, \mathrm{Fe})_{12} \mathrm{As}_{4} \mathrm{~S}_{13}\right]$ (Morrell 1997; Tay 1980; Wodzicki and Weissberg 1970). Although it was first mined for $\mathrm{Pb}, \mathrm{Au}$, and $\mathrm{Ag}$ in the 1880's to the early 1900 's, the mine also provided Zn as a flux to

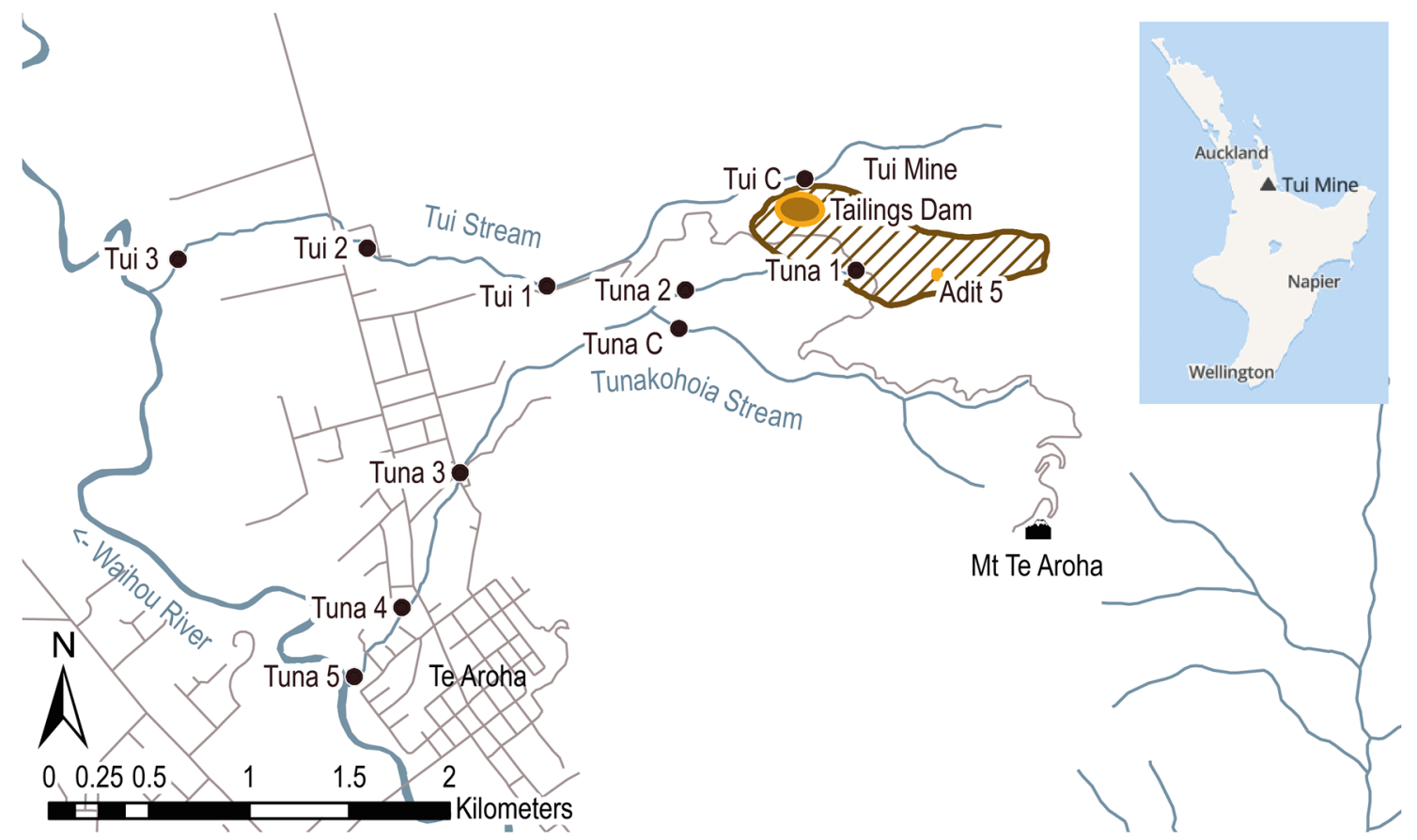

Fig. 1 Map of the study area near Te Aroha in Coromandel, New Zealand, showing the Tui Mine site (hatched) and sampling sites on the Tui and Tunakohoia streams 
gold mining. However, due to primitive ore extraction technology, this early mining did not yield much ore of economic value (Morrell 1997; Tay 1980). In 1967, the mine was reopened by Norpac Mining Ltd to produce $\mathrm{Cu}, \mathrm{Pb}$, and Zn (Morrell 1997) but closed again in 1973 when levels of $\mathrm{Hg}$ found in the ore made it difficult to find a market (Morrell 1997; Tay 1980). The mine site was not rehabilitated but was left with waste rock dumps, an unstable tailings impoundment at risk of collapse, and contaminants leaching from the mine workings, tailings dam, and tailings impoundment. Load calculations by Harvey and WebsterBrown (2003) identified leachate from the tailings dam as the main source of contamination to Tui Stream, and Adit 5 as the main source of contamination to the Tunakohoia Stream. Consequently, the Tui Mine was recognized as New Zealand's worst metal-contaminated site (Sabti et al. 2000) with high levels of metal contaminants in streams draining the site (Table 1). Partial site remediation-replacement of the sediment trap downstream of the tailings dam and the construction of a new spillway at the outlet of the sediment trap-was carried out in 2006 after heavy rain caused the former sediment trap to fail (Sharplin 2008). However, the ranking of most contaminated site in the country, along with perceived instability of the tailings dam in a major seismic or weather event, prompted the local regional and district councils to begin full rehabilitation of the site in 2010 (Fairgray et al. 2016). This project was completed in 2013.

The 2010-2013 rehabilitation included plugging the level 5 adit and modifying the level 4 adit to control the amount of mine drainage water discharged (Fairgray et al. 2016). The underground workings were allowed to flood and lime slurry was injected into the workings. The tailings dam was stabilized, mixed with lime, and capped with clean fill to prevent oxygen and water from entering the tailings. Recent monitoring has shown an apparent improvement in water quality (and ecological health) of the streams, although they do still receive some discharge from the adits and the tailings dam (Fairgray et al. 2016). In Tui Stream, for example, the $\mathrm{pH}$ is now circumneutral and dissolved $\mathrm{Cu}$ and $\mathrm{Pb}$ have been reduced to less than $20 \%$ of their previous concentrations. However, little is known about how the toxicity of dissolved trace elements has changed, and whether this reduction in concentration is sufficient to allow the recovery of a healthy aquatic ecosystem. There is also concern that trace elements in the sediments may continue to be released from the sediment over time, providing an ongoing source of contamination. This has implications for the rate of recovery of this rehabilitated mine site.

\section{Materials and Methods}

\section{Sampling and Analysis}

Water and sediment samples were collected at ten sites in the Tui and Tunakohoia streams; four sites on Tui Stream, including a reference site (TuiC) upstream of the mine workings, and five sites on Tunakohoia Stream, and a reference site (TunaC) on the south branch of the Tunakohoia Stream, which is unaffected by mine drainage (Fig. 1). Samples were collected in spring (November 2015) to avoid the extremes of high rainfall and stream flow during winter, and low stream flow in summer.

Measurements of temperature, $\mathrm{pH}$, electrical conductivity (EC), and dissolved oxygen (DO) were made in situ using a HACH HQ40d portable multi parameter meter. Water samples were collected in high density polyethylene (HDPE) centrifuge tubes. One water sample for major ions determination was collected, as well as two water samples for trace element analysis (one unfiltered, for "acid soluble" trace element analysis, and one filtered through a $0.45 \mu \mathrm{m}$ membrane, for "dissolved" trace element analysis). Both samples were acidified to $1 \% \mathrm{HNO}_{3}$ with Aristar-grade concentrated nitric acid prior to analysis. Sediment samples were collected in HDPE bottles, from the top $5 \mathrm{~cm}$ of the stream sediment bed.

Water samples were analyzed for major cations and trace elements: $\mathrm{Fe}, \mathrm{Mn}, \mathrm{Al}, \mathrm{Cu}, \mathrm{Pb}, \mathrm{Zn}, \mathrm{Cd}, \mathrm{Ni}, \mathrm{Hg}, \mathrm{Sb}$, and $\mathrm{As}$ by inductively coupled plasma mass spectrometry (ICPMS), with detection limits of $0.02 \mathrm{mg} / \mathrm{L}$ for major cations, $1.5 \mu \mathrm{g} / \mathrm{L}$ for $\mathrm{Fe}$ and $\mathrm{Al}$, and $0.05 \mu \mathrm{g} / \mathrm{L}$ for all other trace elements except $\mathrm{Zn}(0.75 \mu \mathrm{g} / \mathrm{L})$ and $\mathrm{Sb}(0.20 \mu \mathrm{g} / \mathrm{L})$. Major anions were determined by high performance ion chromatography, with detection limits of $0.005 \mathrm{mg} / \mathrm{L}$ for $\mathrm{Cl}, 0.020 \mathrm{mg} / \mathrm{L}$ for $\mathrm{NO}_{3}$ and $0.200 \mathrm{mg} / \mathrm{L}$ for $\mathrm{SO}_{4}$. Dissolved inorganic carbon concentrations were determined by infra-red gas analysis,
Table 1 Dissolved trace element concentrations $(\mathrm{mg} / \mathrm{L})$ and $\mathrm{pH}$ in Tui and Tunakohoia Streams, downstream of the Tui mine workings, prior to full rehabilitation in 2010

\begin{tabular}{llllll}
\hline Location & $\mathrm{pH}$ & $\mathrm{Cu}$ & $\mathrm{Pb}$ & $\mathrm{Zn}$ & $\mathrm{Cd}$ \\
\hline Upper Tui Str & $3.50-6.71$ & $1.0-7.0$ & $0.12-3$ & $4.5-1460$ & $0.7-6.0$ \\
Lower Tui Str & $4.4-7.05$ & $1.7-8.0$ & $<0.1-1.04$ & $4-590$ & $0.1-2.0$ \\
Upper Tunakohoia Str & $6.35-7.74$ & $1-110$ & $1-510$ & $1590-16,200$ & $10-140$ \\
Lower Tunakohoia Str & $6.46-7.60$ & $1-30$ & $0.08-260$ & $200-3790$ & $1-100$ \\
\hline
\end{tabular}

References: (Tay 1980; Hendy 1981; Pang 1995; Webster 1995; Harvey and Webster-Brown 2003; Sharplin 2008) 
then reported as $\mathrm{HCO}_{3}{ }^{+}$as all waters were of a neutral $\mathrm{pH}$ (DL $=5.9 \mathrm{mg} / \mathrm{L}$ ).

Sediment samples were dried at $40{ }^{\circ} \mathrm{C}$ and sieved through a $67 \mu \mathrm{m}$ nylon mesh, then digested in hot nitric acid; the digest was analyzed for trace elements by ICP-MS (as above). Sediment samples were also analyzed by X-ray diffraction (XRD) and scanning electron microscopy (SEM). XRD was performed on a Philips 1130 diffractometer over a $2 \theta$ range from $2^{\circ}$ to $62^{\circ}$. Clay separates were glycolated by exposure to ethylene glycol vapors for $48 \mathrm{~h}$ before being run from $2^{\circ}$ to $22^{\circ} 2 \theta$. SEM was carried out on a JEOL JSM IT-300 variable pressure SEM with an Oxford Aztec SDD energy dispersive X-ray analysis system attached.

\section{Sequential Extraction of Sediments}

A sequential chemical extraction scheme based on that of Leleyter and Probst (1999), but including a final hot nitric acid step (Salvarredy-Aranguren et al. 2008), was used to identify the specific solid phases in the sediment that were binding trace elements. The extraction scheme is described in Table 2. A quantity of $0.1 \mathrm{~g}$ of sediment (dried and sieved as for total sediment digestion above) was used, with $10 \mathrm{~mL}$ of the extractant added to the sediment in most steps (volumes of 3-5 mL were used in steps 5 and 6 ). The trace element concentrations in fractions $1,4 \mathrm{a}, 4 \mathrm{~b}, 4 \mathrm{c}, 5$, and 6 of the sequential extraction were analyzed by ICP-MS, and in fractions 2 and 3 were analyzed by ICP-OES (optical emission spectrometry).

As has been acknowledged in the literature, sequential extractions of this nature can be misleading due to the poor specificity of reagents for target mineral phases and the potential redistribution of elements to other phases during the sequential extraction process (Bacon and Davidson 2008). This has been taken into account when interpreting the results in this study. For example, the sodium acetate extractant (fraction 3 ) is often referred to as targeting the "carbonate" fraction, but has been renamed here as "low $\mathrm{pH}$ leachable" fraction to acknowledge the potential for some trace element cations to desorb from mineral surfaces, as well as carbonates and minor $\mathrm{Fe}$ - and $\mathrm{Mn}$-oxyhydroxides to dissolve in this step. The modified nomenclature for target fractions given in Table 2 is used throughout this paper. In addition to this, the sum of each trace element from the fractions in the sequential extraction was compared with the concentration determined by total sediment digest to ensure that redistribution of elements within the fractions was not occurring during the sequential extraction process.

\section{Macroinvertebrate Sampling}

Macroinvertebrate samples were collected in December 2014 according to the protocol of Stark et al. (2001). Samples were preserved in the field with $70 \%$ ethanol. Samples were then sieved through $500 \mu \mathrm{m}$ mesh in the laboratory. Invertebrates were counted and identified to the lowest taxonomic level using the identification guides of Winterbourn et al. (2006).

\section{Geochemical Modelling}

Dissolved trace element speciation, mineral formation or dissolution, and adsorption reactions was predicted using PHREEQC version 3.3.2 with the WATEQ4F thermodynamic database (Parkhurst and Appelo 2013). PHREEQC is the most commonly used geochemical software for predicting mine effluent chemistry in New Zealand, and is commonly used in effluent chemistry prediction internationally (Rötting et al. 2008; Watten et al. 2005). In this study, PHREEQC was used in the two ways it is most commonly used to predict mine discharge chemistry by mining companies and their consultants;

1. To model current dissolved trace element speciation to determine free ion concentrations (to assess potential
Table 2 The sequential extraction scheme of Leleyter and Probst (1999) with an additional final step from Salvarredy-Aranguren et al. (2008)

\begin{tabular}{lll}
\hline Target Fraction & Reagent & Reaction time \\
\hline 1. Water soluble & Deionised water & $30 \mathrm{~min}$ \\
2. Easily exchangeable & $1 \mathrm{M}$ magnesium nitrate & $2 \mathrm{~h}$ \\
3. Low pH leachable & $1 \mathrm{M}$ sodium acetate at $\mathrm{pH}=4.50$ & $5 \mathrm{~h}$ \\
4a. Mn oxides & $0.1 \mathrm{M}$ hydroxylammonium chloride & $30 \mathrm{~min}$ \\
4b. Amorphous Fe oxides & $0.2 \mathrm{M}$ ammonium oxalate $+0.2 \mathrm{M}$ oxalic acid & $4 \mathrm{~h}$ in dark \\
4c. Crystalline Fe oxides & $0.2 \mathrm{M}$ ammonium oxalate $+0.2 \mathrm{M}$ oxalic acid $+0.1 \mathrm{M}$ & $30 \mathrm{~min}$ \\
5. Organic matter & ascorbic acid & $5 \mathrm{~h}$ \\
& $0.02 \mathrm{M} \mathrm{HNO}_{3}+35 \% \mathrm{H}_{2} \mathrm{O}_{2}$ & $30 \mathrm{~min}$ \\
6. Residual (incl. sulfide) & $3.2{\mathrm{M} \mathrm{ammonium} \mathrm{acetate} \mathrm{in} 20 \% \mathrm{v} / \mathrm{v} \mathrm{HNO}_{3}}_{3}$ & $3 \mathrm{~h}$ \\
\hline
\end{tabular}

Extractions were undertaken at $20^{\circ} \mathrm{C}$, except for Fraction $4 \mathrm{c}\left(80^{\circ} \mathrm{C}\right)$ and 5 and $6\left(85^{\circ} \mathrm{C}\right)$ 
toxicity), and to determine speciation change under a regime of changing water quality.

2. To predict dissolved trace element removal through mineral formation and adsorption onto freshly formed hydrous ferric oxide (HFO). For adsorption modelling in a mine remediation context, surface complexation using HFO as the only adsorbing surface is commonly used. This is based on the adsorption data of Dzomback and Morel (1990), which pertains to freshly-formed HFO, with 0.005 strong binding sites $/ \mathrm{mol} \mathrm{Fe}, 0.2$ weak binding sites $/ \mathrm{mol} \mathrm{Fe}$, and a specific surface area of $600 \mathrm{~m}^{2} / \mathrm{g}$.

PHREEQC was used with the WATEQ4F database for dissolved speciation and adsorption. To model dissolved speciation changes following lime additions (e.g. to the tailings pile and inside Adit 5), $125 \mu$ mols of calcite was added stepwise to the stream water from July 2007, as reported by Sharplin (2008) until either the saturation limit $(\mathrm{SI}=0.0)$ of calcite was reached or until $\mathrm{CaCO}_{3}$ was no longer available. $125 \mu$ mols was used as it had been determined that this amount would result in the saturation index of calcite being reached but not exceeded.

Batch reactions were run initially to determine which trace element bearing phases were likely to be supersaturated in the solution, and therefore, which minerals were theoretically most likely to precipitate. The minerals that were unlikely to actually form in a low temperature, freshwater environment were eliminated from consideration. This step discounted the formation of minerals such as hematite, cupric ferrite, and cuprous ferrite, which are only formed at high temperatures (Gholinejad et al. 2014; Kolta et al. 1981). The batch reactions were remodeled with the remaining minerals allowed to precipitate when saturated and the constituent dissolved ion concentrations reduced accordingly. The resulting $\mathrm{pH}$ change was calculated from the ion balance.

\section{Results}

\section{Dissolved Trace Element Concentration, Speciation and Toxicity}

\section{Observed Water Quality}

Physiochemical water quality at the sampling sites during the November 2015 sampling survey is shown in Table 3. A more complete water chemistry (including all major cations and anions, as needed for speciation modelling) is given in Supplemental Tables A1 and A2 (which accompany the online version of this paper).

Remediation at the mine site has effectively raised Tui stream water $\mathrm{pH}$ to circumneutral, and lowered conductivity and sulfate concentrations. However, $\mathrm{pH}$ was already
Table 3 Physiochemical water quality parameters of relevance in determining water trace element speciation and assessing ecological impacts, in the Tui and Tunakohoia streams in November 2015

\begin{tabular}{lcccll}
\hline Site & $\mathrm{pH}$ & Temp ${ }^{\circ} \mathrm{C}$ & $\mathrm{DO}(\mathrm{mg} / \mathrm{L})$ & $\begin{array}{l}\text { Conductiv- } \\
\text { ity }(\mu \mathrm{S} / \mathrm{cm})\end{array}$ & $\mathrm{SO}_{4}(\mathrm{mg} / \mathrm{L})$ \\
\hline Tuna 1 & 7.42 & 13.7 & 9.69 & 666 & 285 \\
Tuna 2 & 7.12 & 12.2 & 10.1 & 409 & 154 \\
Tuna 3 & 6.84 & 13.8 & 9.88 & 308 & 93.6 \\
Tuna 4 & 6.92 & 15.5 & 9.39 & 249 & 65.4 \\
Tuna 5 & 7.52 & 19.6 & 10.1 & 252 & 65.6 \\
Tuna C & 7.07 & 12.1 & 9.85 & 102 & 14.6 \\
Tui 1 & 7.40 & 11.9 & 10.3 & 150 & 29.2 \\
Tui 2 & 7.23 & 12.9 & 9.94 & 150 & 29.6 \\
Tui 3 & 7.31 & 15.9 & 8.98 & 149 & 28.6 \\
Tui C & 7.21 & 11.4 & 9.97 & 125 & 20.1 \\
\hline
\end{tabular}

near neutral in Tunakohoia Stream (Table 1) and the addition of lime in Adit 5 has only had a small effect on $\mathrm{pH}$ and little effect on EC or sulfate concentrations when compared with data of Sharplin (2008). Temperature and DO levels are sufficient to support a healthy ecology, with the possible exception of the elevated temperature at Tuna 5, a shallow section of this stream where it passes through open farm land.

Trace element concentrations are shown in Table 4 as both acid-soluble concentrations (in unfiltered, acidified water samples) and as the percentage of dissolved trace element. Acid soluble $\mathrm{Hg}$ was consistently below detectable levels, as was $\mathrm{Sb}$ at all sites except Tuna $1(0.25 \mu \mathrm{g} / \mathrm{L})$ and Tuna $2(0.13 \mu \mathrm{g} / \mathrm{L})$. The concentrations of trace elements were considerably higher in Tunakohoia Stream, which still receives drainage from Adit 5, than in Tui Stream.

In New Zealand, any initial assessment of potential trace element toxicity to aquatic life compares acid-soluble concentrations with trigger values in the ANZECC (2000) water quality guidelines. For "moderately disturbed" streams, trigger values represent the highest trace element concentration that will still protect $95 \%$ of the aquatic species present. They are referred to as trigger values to indicate they are only the first stage of a toxicity assessment. If they are exceeded, further investigations, such as trace element speciation determination, are required to better assess the toxicity of the contaminant (ANZECC 2000).

Acid-soluble $\mathrm{Zn}$ and Cd exceeded ANZECC (2000) trigger values in both streams, but most significantly in Tunakohoia Stream. Notably, the $\mathrm{Zn}$ trigger value was even exceeded (slightly) at the reference site (TuiC), upstream of any tailings drainage input, likely reflecting natural elevation due to the weathering of host rock. In addition, the dissolved fraction of these metals constituted $85-100 \%$ of the acidsoluble concentration at the contaminated sites, indicating that most of the element was bioavailable. 
Table 4 Acid-soluble trace element concentrations $(\mu \mathrm{g} / \mathrm{L})$, together with percentage dissolved concentration (in parentheses) in the Tui and Tunakohoia Streams, as measured in November 2015

\begin{tabular}{lllllllll}
\hline Site & $\mathrm{Fe}$ & $\mathrm{Mn}$ & $\mathrm{Cu}$ & $\mathrm{Pb}$ & $\mathrm{Zn}$ & $\mathrm{Cd}$ & $\mathrm{Ni}$ & $\mathrm{As}$ \\
\hline Tuna 1 & 360 & 453 & $\mathbf{4 . 9 4}$ & $\mathbf{1 6 . 5}$ & $\mathbf{2 4 4 0}$ & $\mathbf{1 5 . 2}$ & 7.79 & 1.52 \\
& $(1 \%)$ & $(100 \%)$ & $(56 \%)$ & $(14 \%)$ & $(100 \%)$ & $(100 \%)$ & $(100 \%)$ & $(73 \%)$ \\
Tuna 2 & 14.9 & 75.3 & $\mathbf{5 . 0 6}$ & $\mathbf{5 . 0 4}$ & $\mathbf{1 8 6 0}$ & $\mathbf{1 3 . 2}$ & 3.73 & 0.56 \\
& $(21 \%)$ & $(100 \%)$ & $(76 \%)$ & $(49 \%)$ & $(99 \%)$ & $(100 \%)$ & $(100 \%)$ & $(100 \%)$ \\
Tuna 3 & 11.3 & 1.85 & 1.03 & 0.19 & $\mathbf{5 9 6}$ & $\mathbf{6 . 1 1}$ & 1.33 & 0.41 \\
& $(82 \%)$ & $(95 \%)$ & $(89 \%)$ & $(68 \%)$ & $(100 \%)$ & $(100 \%)$ & $(100 \%)$ & $(100 \%)$ \\
Tuna 4 & 31.3 & 5.15 & 0.94 & 0.20 & $\mathbf{3 5 2}$ & $\mathbf{4 . 1 4}$ & 0.88 & 0.39 \\
& $(42 \%)$ & $(78 \%)$ & $(84 \%)$ & $(50 \%)$ & $(97 \%)$ & $(94 \%)$ & $(100 \%)$ & $(100 \%)$ \\
Tuna 5 & 64.2 & 20.9 & 1.54 & 0.68 & $\mathbf{1 9 4}$ & $\mathbf{2 . 6 7}$ & 0.70 & 0.47 \\
& $(41 \%)$ & $(98 \%)$ & $(74 \%)$ & $(15 \%)$ & $(93 \%)$ & $(90 \%)$ & $(93 \%)$ & $(93 \%)$ \\
Tuna C & 32.0 & 3.58 & 0.40 & 0.17 & 1.03 & $<\mathrm{DL}$ & 0.21 & 0.26 \\
& $(26 \%)$ & $(13 \%)$ & $(82 \%)$ & $(19 \%)$ & $(79 \%)$ & - & $(80 \%)$ & $(100 \%)$ \\
Tui 1 & 7.61 & 1.13 & 0.95 & 0.23 & $\mathbf{4 6 . 8}$ & $\mathbf{0 . 3 7}$ & 0.57 & 0.44 \\
& $(38 \%)$ & $(35 \%)$ & $(89 \%)$ & $(23 \%)$ & $(98 \%)$ & $(97 \%)$ & $(100 \%)$ & $(100 \%)$ \\
Tui 2 & 31.7 & 11.8 & 1.01 & 0.11 & $\mathbf{5 5 . 3}$ & $\mathbf{0 . 4 3}$ & 0.58 & 0.49 \\
& $(64 \%)$ & $(89 \%)$ & $(89 \%)$ & $(25 \%)$ & $(97 \%)$ & $(89 \%)$ & $(96 \%)$ & $(96 \%)$ \\
Tui 3 & 169 & 51.3 & 1.26 & 0.41 & $\mathbf{3 9 . 5}$ & $\mathbf{0 . 2 7}$ & 0.60 & 0.91 \\
& $(39 \%)$ & $(93 \%)$ & $(75 \%)$ & $(21 \%)$ & $(95 \%)$ & $(85 \%)$ & $(99 \%)$ & $(96 \%)$ \\
Tui C & 38.2 & 2.36 & 0.29 & 0.11 & $\mathbf{1 1 . 0}$ & 0.07 & 0.21 & 0.48 \\
& $(7 \%)$ & $(9 \%)$ & $(59 \%)$ & $(8 \%)$ & $(88 \%)$ & $(94 \%)$ & $(76 \%)$ & $(93 \%)$ \\
ANZECC & & 1900 & 1.4 & 3.4 & 8.0 & 0.20 & 11 & 13 \\
ger value & & & & & & & & \\
\hline
\end{tabular}

Values in bold exceed "ANZECC" trigger values, local water quality guidelines for the protection 95\% of aquatic life present (ANZECC 2000)
Of the other trace elements tested, only $\mathrm{Cu}$ and $\mathrm{Pb}$ exceed trigger values, and then only in the upper reaches of the Tunakohoia Stream. The proportion of dissolved (bioavailable) $\mathrm{Cu}$ and $\mathrm{Pb}$ is also less than for $\mathrm{Cd}$ and $\mathrm{Zn}$, with dissolved $\mathrm{Cu}$ constituting 56-89\%, and $\mathrm{Pb}$ constituting 8-68\% of their acid-soluble concentrations. Other trace elements (Fe, Mn, As, and Ni) did not exceed (ANZECC 2000) guidelines; therefore, further assessment of potential toxicity focuses on $\mathrm{Zn}, \mathrm{Cd}, \mathrm{Cu}$ and $\mathrm{Pb}$.

\section{Modelled Dissolved Trace Element Speciation}

For dissolved trace element concentrations exceeding ANZECC (2000) trigger values, PHREEQC was used to determine the proportion of the trace element present in the free ion form. The free ion is assumed to be most toxic species to biota according to the free ion activity model (Campbell 1995).

Figure 2 shows PHREEQC predicted dissolved $\mathrm{Cd}, \mathrm{Cu}$, $\mathrm{Pb}$, and $\mathrm{Zn}$ concentrations. The concentrations of free $\mathrm{Cu}^{2+}$ and $\mathrm{Pb}^{2+}$ ions are predicted to be well below ANZECC (2000) guidelines at all sites, including the upper Tunakohoia Stream, as these metals are complexed by hydroxyl ligands. Free $\mathrm{Cu}^{2+}$ ion constituted only up to $40 \%$ of the dissolved $\mathrm{Cu}$ in Tunakohoia Stream, and up to $15 \%$ in the Tui Stream. Free $\mathrm{Pb}^{2+}$ ion constituted less than $35 \%$ of the dissolved $\mathrm{Pb}$ in the Tunakohoia Stream and up to $20 \%$ in the Tunakohoia Stream.

However, free $\mathrm{Cd}^{2+}$ and $\mathrm{Zn}^{2+}$ ions remained orders of magnitude higher than the ANZECC (2000) guidelines, for all except the reference sites. The main complexing ligand for $\mathrm{Zn}$ and $\mathrm{Cd}$ was the sulfate ion, although sulfate complexes made up $<25 \%$ of the dissolved $\mathrm{Cd}$ and $\mathrm{Zn}$ in the Tunakohoia and $<5 \%$ in Tui Stream.

\section{Consistency with Ecological Monitoring Data}

The modelled concentration of $\mathrm{Zn}^{2+}$ and $\mathrm{Cd}^{2+}$ ions were compared to the results of the ecological surveys carried out at these sites (Fig. 3). In Tunakohoia stream, there appears to be a reduction in ecological taxa at $>3.5 \mu \mathrm{g} / \mathrm{L}$ free $\mathrm{Cd}$ ion and $>300 \mu \mathrm{g} / \mathrm{L}$ free $\mathrm{Zn}$ ion. However, as high concentrations of $\mathrm{Zn}$ and $\mathrm{Cd}$ occur simultaneously, it is not possible to state with confidence which of these metals has the greatest detrimental effect on aquatic life. In Tui Stream, ecological effects appear to occur at much lower concentrations, and may be due to other factors, such as the long term low $\mathrm{pH}$ that occurred in this stream prior to mine remediation. 


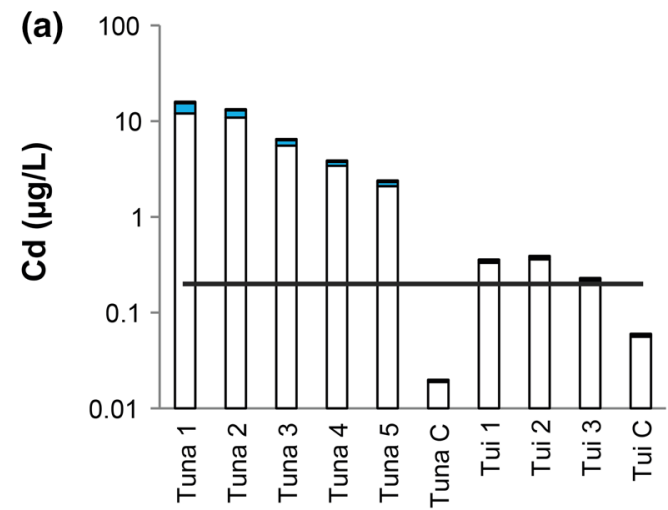

(c)

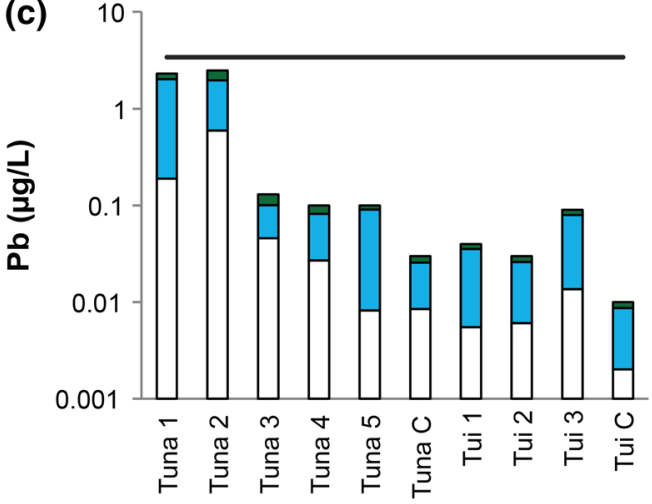

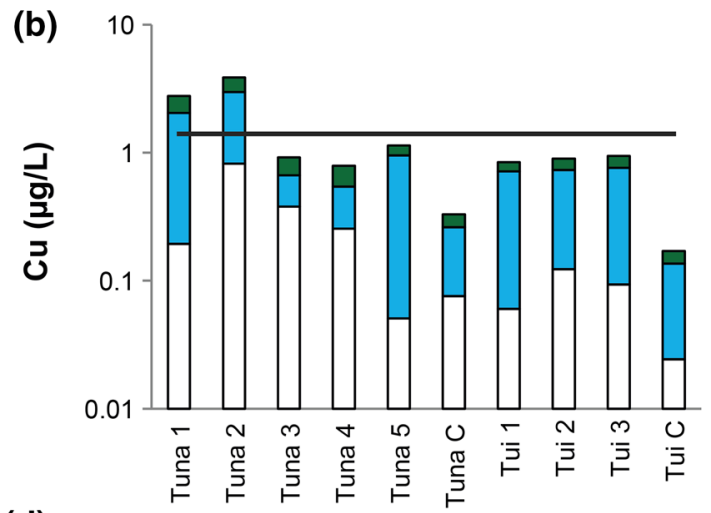

(d) 10,000

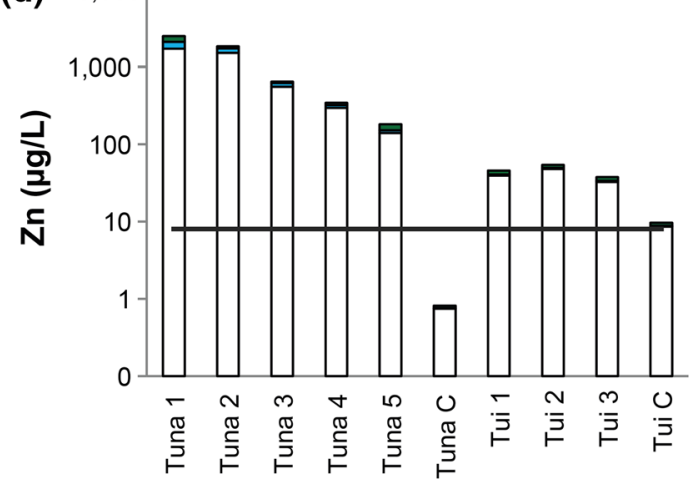

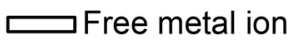

$\square$ Most common complex

$\square$ Other complexes

Protect 95\% aquatic species

Fig. 2 Speciation of elements exceeding ANZECC (2000) trigger values in Tui and Tunakohoia streams, showing the relevant water quality guideline to protect $95 \%$ of aquatic life

\section{Sediment-bound Trace Element Speciation}

\section{Observed Sediment Mineralogy and Chemistry}

XRD analysis showed that the sediment minerals were predominantly quartz and plagioclase, with chlorite, smectite, illite, and kaolinite clays present as weathering products. No major trace element bearing minerals were identified by XRD. SEM analysis revealed a residual $\mathrm{Zn}$-sulfide particle in Tuna 1 sediment just below Adit 5 drainage (Fig. 4), but no other sulfide minerals. No residual carbonates (such as limestone fragments from the remediation activities) or secondary carbonate phases were observed in the sediments. However, strong mineralogical associations between $\mathrm{Fe}, \mathrm{Pb}$, and $\mathrm{Cu}$, and between $\mathrm{Mn}$ and $\mathrm{Zn}$ were observed (examples shown in Fig. 4).

Sediment-bound trace element concentrations are shown in Table 5. ANZECC (2000) interim sediment quality guidelines (ISQG) for aquatic life protection are also shown; ISQG-High is the guideline above which an adverse biological effect is frequently observed, and ISQG-Low is the guideline below which adverse effects rarely occur. For values between these two guidelines, adverse effects occur occasionally (ANZECC 2000; Long et al. 1995). ANZECC (2000) sediment quality guidelines are not available for $\mathrm{Fe}$, $\mathrm{Mn}$, or Al.

Fe concentrations were most elevated in the upper reaches of the streams, closest to the mine discharges, up to $11.4 \%$ in Tunakohoia Stream (Tuna 1) and $7.1 \%$ in Tui Stream (Tui 1 and 2), but close to background levels elsewhere (3.3-5.2\%). Mn was similarly elevated below Adit 5 (3.3\%) at Tuna 1 and high immediately below the tailings dam at Tui 1 and 2 (0.34-0.43\%), but not significantly elevated downstream. Copious brown Fe oxyhydroxide floc was evident in the upper reaches of both streams; however, the dissolved $\mathrm{Fe}$ concentration appeared to increase particularly in Tui Stream. This may, however, be a result of the filtration method as, in the lower reaches, $\mathrm{Fe}$ oxide flocs were not as visible, and presumably present as smaller particulates, of which some could have passed through a $0.45 \mu \mathrm{m}$ filter to register as "dissolved" $\mathrm{Fe}$ in the stream.

The Tunakohoia and Tui stream sediments were severely contaminated with $\mathrm{Zn}, \mathrm{Pb}$, and $\mathrm{Cd}$, particularly in the upper reaches where concentrations were well above ANZECC 

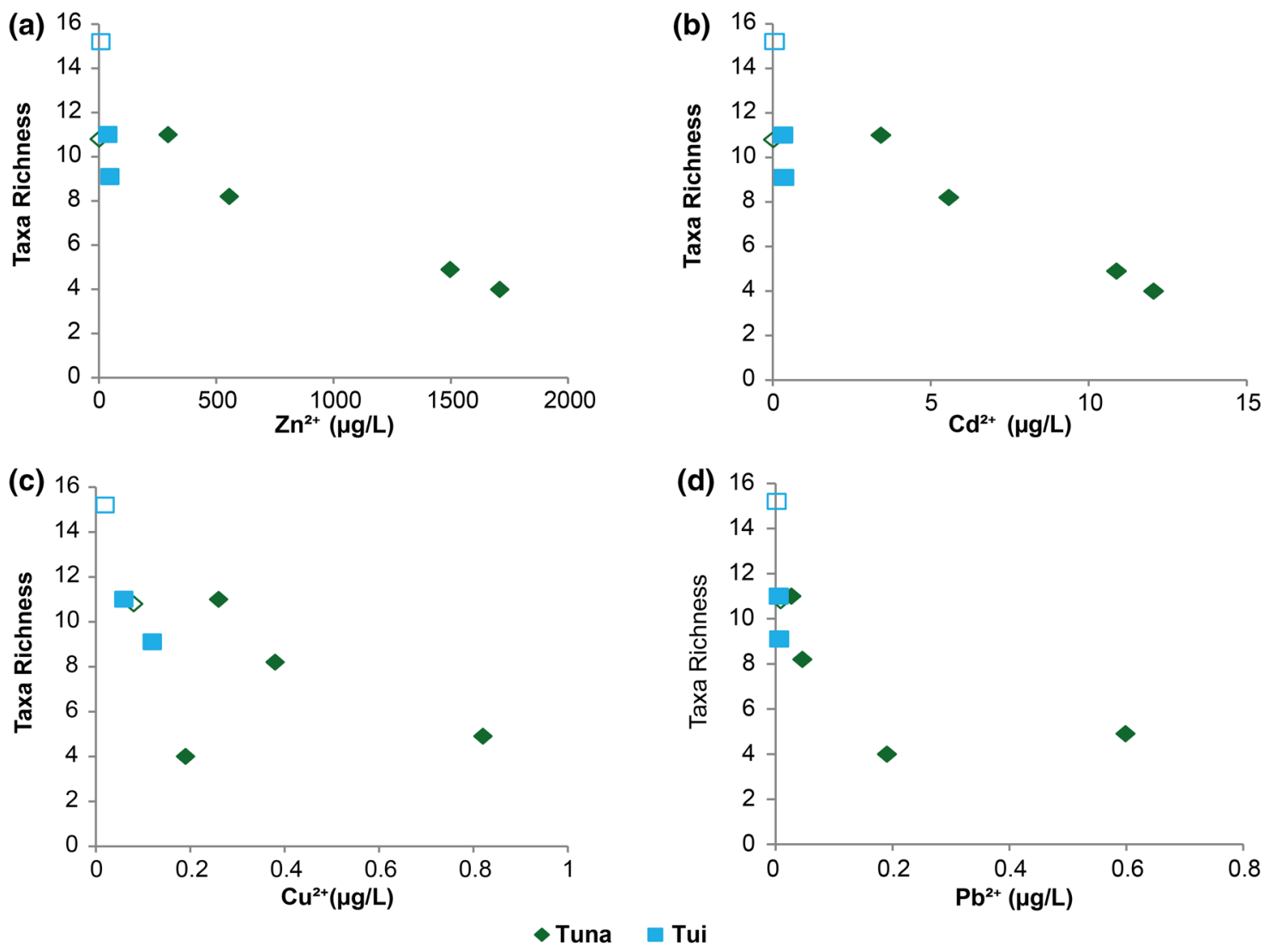

Fig. 3 Ecological taxa richness compared to free $\mathrm{Zn}$ and $\mathrm{Cd}$ ion activity in Tunakohoia and Tui streams. Reference sites are shown as open symbols

(2000) ISQG-High guideline values. Concentrations of up to $4.5 \% \mathrm{Zn}$ and $1.2 \% \mathrm{~Pb}$ were present in the sediments immediately below Adit 5 drainage (Tuna 1 site) and these sediments also showed high concentrations of $\mathrm{Cu}, \mathrm{Ni}, \mathrm{As}$, $\mathrm{Sb}$, and $\mathrm{Hg}$. Ni was also high immediately below the tailings dam drainage in Tui Stream and, unexpectedly, at the reference site TunaC.

\section{Modelled Trace Element Precipitation}

Modelling carried out using dissolved trace element concentrations showed that once high-temperature phases were discounted, the only trace element-bearing phases that were saturated were oxides of $\mathrm{Fe}, \mathrm{Mn}$, and $\mathrm{Al}$. No carbonate minerals of trace elements, such as calcite $\left(\mathrm{CaCO}_{3}\right)$, rhodochrosite $\left(\mathrm{MnCO}_{3}\right)$, smithsonite $\left(\mathrm{ZnCO}_{3}\right)$, otavite $\left(\mathrm{CdCO}_{3}\right)$, cerrusite $\left(\mathrm{PbCO}_{3}\right), \mathrm{CuCO}_{3}$, or mixed hydroxycarbonates, such as malachite $\left[\mathrm{Cu}_{2}(\mathrm{OH})_{2} \mathrm{CO}_{3}\right]$ and azurite $\left[\mathrm{Cu}_{3}(\mathrm{OH})_{2}\left(\mathrm{CO}_{3}\right)_{2}\right]$ were saturated at the site. Sulfides of the trace elements, such as sphalerite $(\mathrm{ZnS})$, chalcopyrite $\left(\mathrm{CuFeS}_{2}\right)$, or galena $(\mathrm{PbS})$, were also not saturated in the stream waters due to the redox state of the water favoring $\mathrm{SO}_{4}$ over $\mathrm{HS}$. This indicates that the removal of trace elements from the water column is not likely due to mineral precipitation for $\mathrm{Zn}, \mathrm{Cd}, \mathrm{Cu}$, or $\mathrm{Pb}$. This also highlights the importance of HFO or ferrihydrite as a key to trace element removal in these streams due to the adsorption of trace elements to the HFO surface.

\section{Sequential Extraction of Sediments}

Sequential extraction results confirmed that $\mathrm{Fe}$ and $\mathrm{Mn}$ were predominantly bound in their respective hydrous oxide phases (Fig. 5a and b). For Mn, this was especially notable at Tuna 1 and Tuna 2 where the total Mn content was very high. A higher proportion of Mn was extracted from the Fe oxide fractions for the Tui stream and Tuna 3 sediment samples. $10-15 \%$ of the Fe in the Tui sediments appears to have been in a residual sulfide fraction.

As and $\mathrm{Sb}$ were principally extracted from the Fe oxide fractions (Fig. $5 \mathrm{~g}, \mathrm{~h}$ ), almost to the exclusion of all other fractions. Most of the $\mathrm{Zn}, \mathrm{Cu}$, and $\mathrm{Pb}$ was extracted in either the low pH leachable, or Fe oxide fractions (Fig. 5c-e). The Fe oxide fraction was of greatest importance downstream in the both streams. $\mathrm{Pb}$ and $\mathrm{Zn}$ also showed some (less) affinity for the $\mathrm{Mn}$ oxide fraction, and $\mathrm{Cu}$ and $\mathrm{Zn}$ for the "organic" fraction. However, $\mathrm{Cu}, \mathrm{Zn}$ and $\mathrm{Pb}$ in the sulfide and residual 
fraction was $<3 \%$ for all sites, indicating that residual sulfide minerals such as chalcopyrite, sphalerite, and galena make an insignificant contribution to sediment chemistry, despite sphalerite being observed with SEM (Fig. 4a).

In contrast, $\mathrm{Cd}$ showed little affiliation with the Fe oxide fractions (Fig. 5f). Cd was instead mainly extracted from the low $\mathrm{pH}$ leachable fraction in the upper Tunakohoia Stream sediments, and from the low $\mathrm{pH}$ leachable and exchangeable fractions at Tuna 3 and in the Tui Stream sediments. We note that low $\mathrm{pH}$ leachable can include leaching from $\mathrm{Fe}$ oxide mineral surfaces at $\mathrm{pH} 4.5$.

The sum of trace elements from the fractions extracted was within $30 \%$ of the concentration determined by total sediment digest for all samples except for Tuna 2, which had a significantly greater amount of $\mathrm{Mn}, \mathrm{Cu}, \mathrm{Pb}, \mathrm{Zn}$, and $\mathrm{Cd}$ for the sequential extraction process. This is more likely due to a non-homogeneous sample than an error in the sequential extraction process.

\section{Modelled Adsorption of Trace Elements onto HFO}

PHREEQC was used to characterize the degree of adsorption onto fresh HFO present in the water column and surface sediment. We assumed that the concentration of fresh HFO was equal to the amount of particulate Fe in each water sample, as calculated from the difference between the dissolved and acid soluble Fe concentrations. PHREEQC dissolved trace element concentrations are compared to observed concentrations in Fig. 6.

PHREEQC reliably predicted the dissolved proportion of $\mathrm{Zn}, \mathrm{Cd}, \mathrm{Ni}$, which were all predominantly dissolved. It also predicted the proportion of dissolved $\mathrm{Cu}$ reasonably well (within $20 \%$ of observed dissolved concentrations, generally overestimated). PHREEQC overestimated dissolved concentrations to a greater extent at the control sites and the lower catchment waters, indicating additional binding processes (unrelated to HFO adsorption) may be more important for $\mathrm{Cu}$ in these waters.

However, PHREEQC was less reliable when predicting the proportion of dissolved $\mathrm{Pb}$ and As. For $\mathrm{Pb}$, PHREEQC overestimated the proportion of dissolved $\mathrm{Pb}$ for all sites except for the control sites and Tui 3. Although little of the $\mathrm{Zn}$ was predicted to adsorb to the HFO, the very high concentration of this trace element in the stream water meant that it still occupied a large portion of the HFO binding sites, inhibiting the adsorption of other trace elements. When $\mathrm{Zn}$ adsorption was completely excluded, more $\mathrm{Pb}$ bound to the strong binding sites on HFO and the amount of dissolved $\mathrm{Pb}$ therefore decreased. The reliability of $\mathrm{Pb}$ modelling is therefore likely to be sensitive to competition for binding sites when there are such high concentrations of $\mathrm{Zn}$ present.

For As, PHREEQC consistently predicted a high degree of adsorption to the HFO present, which was clearly not occurring as dissolved As was observed to constitute $73-100 \%$ of the acid-soluble As. Using only $2-3 \%$ of the HFO surface actually available in the model provided a better estimate of the amount of As adsorbed, as was also noted when modelling geothermal As adsorption in lowland rivers (Webster-Brown and Lane 2005).

\section{Modelling Speciation Change with Limestone Addition}

The remediation of Tui mine included the addition of crushed limestone to both the tailings pile and Adit 5 to increase $\mathrm{pH}$. This was anticipated to reduce trace element toxicity by complexation, and to facilitate the removal of dissolved trace elements by precipitation and adsorption. If these changes in trace element speciation can be collectively and reliably modelled, this can be used to support remediation decisions.

Where the mineral formed is HFO, the adsorption of cationic trace elements, such as $\mathrm{Cu}, \mathrm{Pb}, \mathrm{Zn}$, and $\mathrm{Cd}$, is expected to increase with $\mathrm{pH}$, while the adsorption of anionic trace elements such as As decreases under the same conditions. Figure 7 demonstrates this trend for $\mathrm{Cu}, \mathrm{Pb}, \mathrm{Zn}$, and $\mathrm{As}$ adsorption under a regime of increasing $\mathrm{pH}$, for the temperature and HFO concentration present at the Tunal site. This shows that where both cationic and anionic trace elements are present at toxic concentrations, modelling can be used to find the stream $\mathrm{pH}$ that will result in the optimum cationic and anionic trace elements adsorption onto HFO.

In terms of mineral precipitation, PHREEQC was used to add calcite $\left(\mathrm{CaCO}_{3}\right)$ stepwise to pre-remediation stream waters, until saturation with respect to calcite was reached. The pre-remediation composition of water at the Tuna 1 and Tuil sites, as reported for July 2007 (Sharplin 2008), was used and the electron potential (pe) was set to 12 , to reflect the fast-flowing, fully-oxygenated stream waters. The results are shown in Fig. 8 for pre-remediation Tui 1 stream water, and Fig. 9 for pre-remediation Tuna 1 stream water. The same amount of limestone $\left(125 \mu \mathrm{mol}\right.$ of $\left.\mathrm{CaCO}_{3}\right)$ added to each stream water yielded quite different results: Tui 1, which had a starting $\mathrm{pH}$ of 6.5 , could be raised to 9.0 before the solution became saturated with $\mathrm{CaCO}_{3}$, whereas Tuna 1 , which had a starting $\mathrm{pH}$ of 7.16 , could only be raised to 7.67 with the same amount of $\mathrm{CaCO}_{3}$, and did not reach saturation with respect to $\mathrm{CaCO}_{3}$. This shows the diminished return of trying to achieve a $\mathrm{pH}$ increase with limestone in a near-neutral, well buffered stream such as Tunakohoia Stream, compared to Tui Stream. The $\mathrm{pH}$ actually measured in the streams during this study was around 7.4 for both streams, indicating that the reaction had progressed approximately halfway along these projected trajectory paths.

In both examples, the predicted concentrations of dissolved Fe were well below the measured concentrations, with the solution being saturated with respect to HFO. This 
(a)

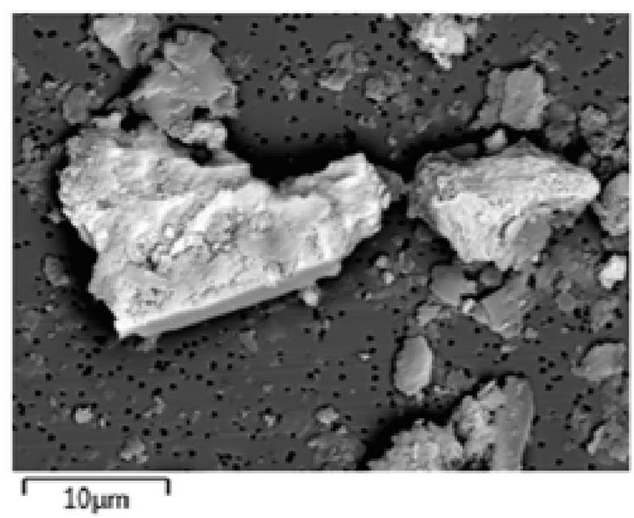

(c)

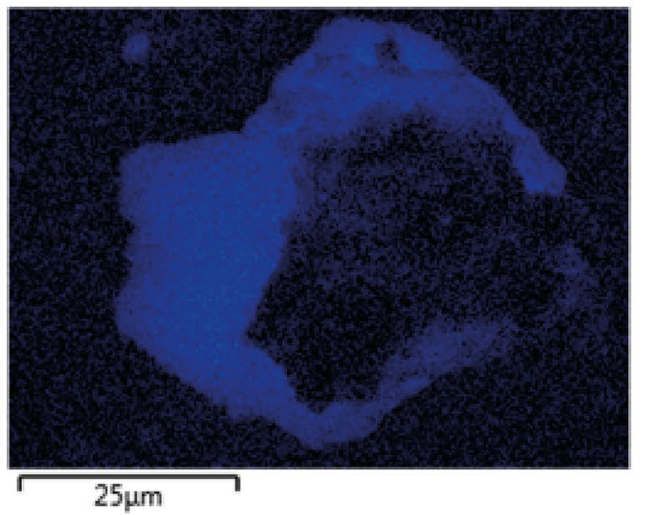

(e)

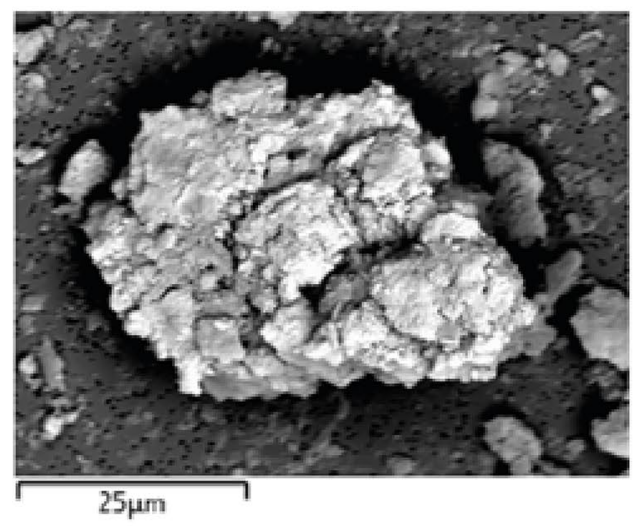

(g)

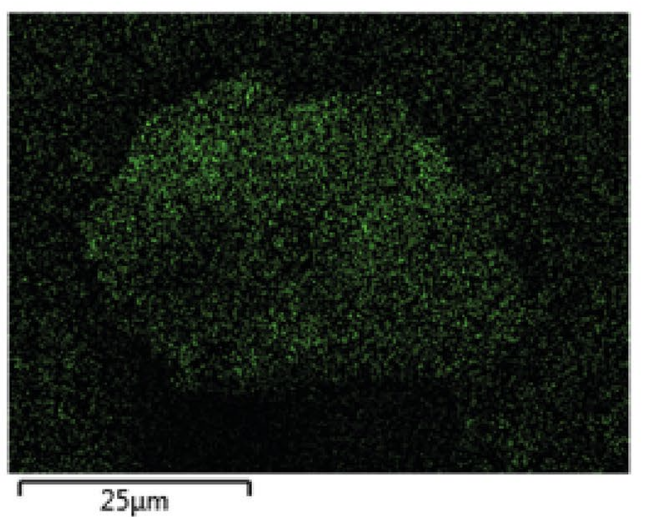

(b)

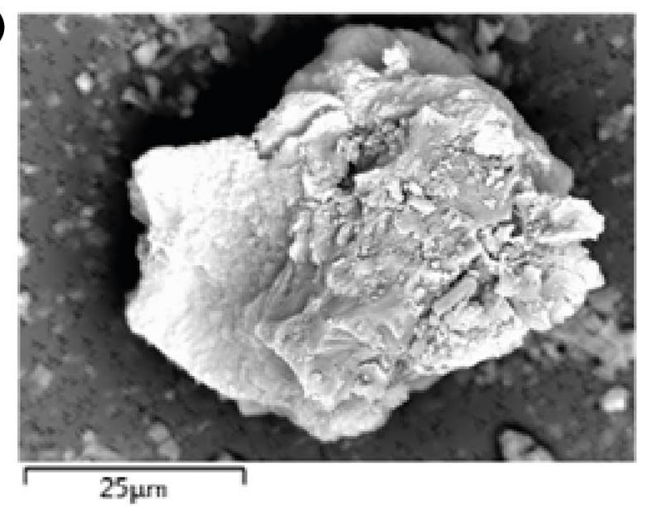

(d)

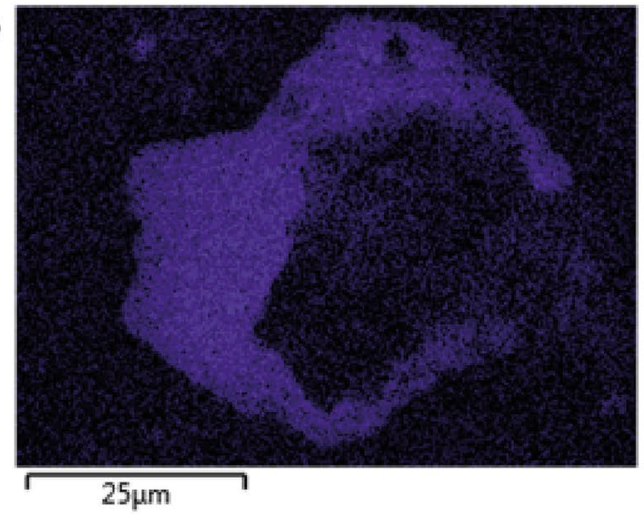

(f)

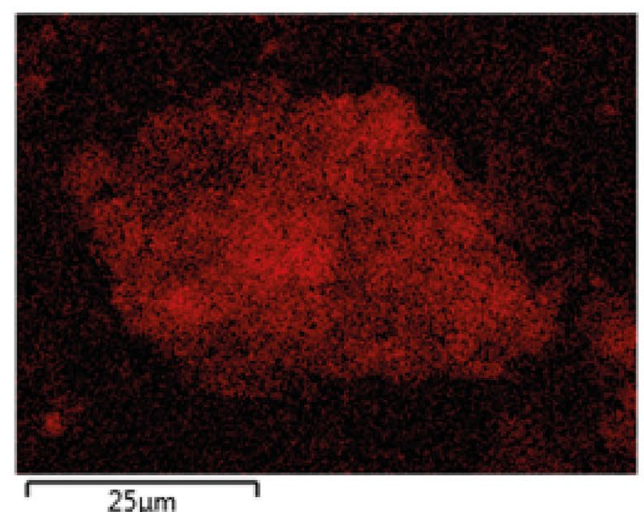

(h)

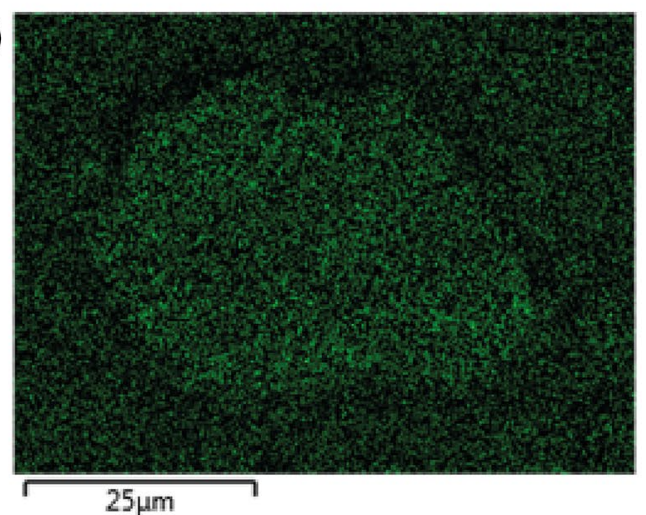


४Fig. 4 Scanning electron microscope images of; a a sphalerite particle (Zn 35.4\% and S 17.2\%) from site Tuna1; b a particle showing a strong Mn-Zn association, with high Mn density (c) and high $\mathrm{Zn}$ density (d); e a particle showing an $\mathrm{Fe}-\mathrm{Pb}-\mathrm{Cu}$ association, with high $\mathrm{Fe}$ density (f), high $\mathrm{Pb}$ density (g), and high $\mathrm{Cu}$ density (h)

effect became more pronounced at higher $\mathrm{pH}$. The discrepancy between predicted and measured dissolved Fe concentrations in commonly reported and attributed to the ability of fine HFO colloids to pass through $0.45 \mu \mathrm{m}$ filters and be included in "dissolved" Fe concentrations. Dissolved Fe decreased markedly with increased $\mathrm{pH}$, and was predominantly complexed with hydroxide.

Dissolved $\mathrm{Mn}$ and $\mathrm{Zn}$ were also predicted to decrease significantly, but only above $\mathrm{pH} 8$ (i.e. in Tui Stream), when water became saturated with respect to rhodocrosite $\left(\mathrm{MnCO}_{3}\right), \mathrm{ZnO}$, and $\mathrm{Zn}(\mathrm{OH})_{2}$. Free $\mathrm{Mn}^{2+}$ and $\mathrm{Zn}^{2+}$ remained the dominant species. Saturation with respect to rhodochrosite was also achieved in the Tunal model, but did not significantly reduce the concentration of $\mathrm{Mn}$ or $\mathrm{Mn}^{2+}$. The $\mathrm{Mn}$ and $\mathrm{Zn}$ concentrations measured in both streams were much less than predicted, indicating that additional precipitation or adsorption reactions were occurring.

For both streams, no change in dissolved $\mathrm{Cd}, \mathrm{Cu}$, or $\mathrm{Pb}$ concentrations were predicted to occur over the $\mathrm{pH}$ range investigated, as no $\mathrm{Cd}, \mathrm{Cu}$, or Pb-bearing minerals were predicted to reach saturation. However, the concentrations of $\mathrm{Cu}^{2+}$ and $\mathrm{Pb}^{2+}$ were predicted to decreased in the Tuil water, as $\mathrm{Cu}(\mathrm{OH})_{2}^{0}$ and $\mathrm{PbCO}_{3}^{0}$ became the dominant dissolved species. In the Tunal solution, $\mathrm{Cu}^{2+}$ and $\mathrm{Pb}^{2+}$ were already low as $\mathrm{Cu}(\mathrm{OH})_{2}^{0}$ and $\mathrm{PbCO}_{3}^{0}$ were the dominant species at the starting $\mathrm{pH}$. Neither the concentration nor percentage of $\mathrm{Cd}^{2+}$ was predicted to decrease significantly in either water. The concentrations of $\mathrm{Cd}, \mathrm{Cu}$, and $\mathrm{Pb}$ were measured to be much lower at Tui 1 , indicating additional precipitation or adsorption reactions occurring. Cd was measured to be much less at Tuna 1, but $\mathrm{Cu}$ and $\mathrm{Pb}$ concentrations were slightly higher, although similar, to those measured in 2007.

\section{Discussion}

The full characterization of the stream water and sediment geochemistry revealed that, even following the rehabilitation of the Tui mine site in 2013, there are still very high concentrations of some trace elements in the water and sediment of Tunakohoia Stream and upper reaches of the Tui stream. In November 2015, dissolved Zn and Cd concentrations were still above guidelines for the protection of aquatic life at all sites except the control site on Tunakohoia Stream, and the dissolved $\mathrm{Cu}$ concentration was still above these guidelines in the upper reaches of the stream. The addition of lime slurry to the adits draining to Tunakohoia Stream has not reduced the concentration of either $\mathrm{Cd}$ or $\mathrm{Zn}$ significantly, and certainly not enough to restore a healthy aquatic ecosystem. Nor has lime addition raised the $\mathrm{pH}$ of the adit drainage, which has always been high (circumneutral) relative to the more acidic drainage from the tailings dam (Hendy 1981; Sharplin 2008; Tay 1980; Webster 1995). The rehabilitation of the tailings dam has, however, been more effective, increasing $\mathrm{pH}$ to near-neutral and decreasing the concentration of trace elements, such that only $\mathrm{Cd}$ and $\mathrm{Zn}$ remain above guideline values. Ecological surveys have shown an improvement in Tui Stream health, but overall a strong negative correlation between macroinvertebrate taxa richness and the concentration of $\mathrm{Zn}^{2+}$ and $\mathrm{Cd}^{2+}$ (Fairgray et al. 2016).

Additionally, the concentrations of $\mathrm{Cu}, \mathrm{Pb}, \mathrm{Zn}, \mathrm{Cd}, \mathrm{Ni}$, $\mathrm{As}, \mathrm{Sb}$, and $\mathrm{Hg}$ in the sediment of these streams is elevated and at a level likely impacting aquatic life. In the sediment, strong associations with $\mathrm{Mn}$ - or Fe-oxide phases were
Table 5 Trace element concentrations $(\mathrm{mg} / \mathrm{kg}$, except for $\mathrm{Fe}, \mathrm{Mn}$ and $\mathrm{Al}$ in \%) in fine sediment $(<0.67 \mu \mathrm{m}$ fraction $)$ in streams receiving Tui Mine drainage, as measured in November 2015

\begin{tabular}{llllllllllll}
\hline Site & $\mathrm{Fe}$ & $\mathrm{Mn}$ & $\mathrm{Al}$ & $\mathrm{Cu}$ & $\mathrm{Pb}$ & $\mathrm{Zn}$ & $\mathrm{Cd}$ & $\mathrm{Ni}$ & $\mathrm{As}$ & $\mathrm{Sb}$ & $\mathrm{Hg}$ \\
\hline Tuna 1 & 11.4 & 3.31 & 3.34 & $\mathbf{2 1 6 0}$ & $\mathbf{1 1 , 6 0 0}$ & $\mathbf{4 5 , 6 0 0}$ & $\mathbf{2 5 4}$ & $\mathbf{1 1 2}$ & $\mathbf{2 2 1}$ & 5.91 & $\mathbf{6 . 1 4}$ \\
Tuna 2 & 4.69 & 0.206 & 5.60 & $\mathbf{1 6 8}$ & $\mathbf{6 1 1}$ & $\mathbf{4 2 8 0}$ & $\mathbf{2 2 . 8}$ & 49.0 & 26.6 & 0.46 & $<0.01$ \\
Tuna 3 & 4.83 & 0.210 & 5.89 & 149 & $\mathbf{5 9 9}$ & $\mathbf{4 2 3 0}$ & $\mathbf{2 1 . 8}$ & 50.3 & 26.2 & 0.56 & 0.974 \\
Tuna 4 & 4.24 & 0.150 & 4.08 & 103 & $\mathbf{3 9 7}$ & $\mathbf{3 2 9 0}$ & $\mathbf{1 4 . 4}$ & 45.7 & 17.3 & 0.47 & $<0.01$ \\
Tuna 5 & 3.34 & 0.119 & 5.53 & 29.4 & 26.7 & 91.0 & 0.505 & 39.7 & 14.5 & 0.22 & $<0.01$ \\
Tuna C & 4.83 & 0.175 & 4.22 & 46.2 & 38.0 & 120 & 0.553 & $\mathbf{5 3 . 7}$ & 16.7 & 0.10 & $<0.01$ \\
Tui 1 & 7.14 & 0.338 & 6.95 & 249 & $\mathbf{4 3 4}$ & $\mathbf{3 4 6 0}$ & $\mathbf{1 6 . 6}$ & $\mathbf{8 8 . 8}$ & 54.1 & 0.78 & 0.071 \\
Tui 2 & 7.14 & 0.430 & 5.76 & 277 & $\mathbf{5 2 1}$ & $\mathbf{3 3 2 0}$ & $\mathbf{2 3 . 5}$ & $\mathbf{9 0 . 4}$ & $\mathbf{6 2 . 3}$ & 0.71 & 0.57 \\
Tui 3 & 4.05 & 0.145 & 4.00 & 85.2 & 145 & $\mathbf{7 6 7}$ & 4.34 & 38.1 & 22.5 & 0.16 & $<0.01$ \\
Tui C & 5.18 & 0.0946 & 5.63 & 43.9 & 35.9 & 402 & 1.58 & 49.5 & 30.6 & 0.10 & $<0.01$ \\
ISQG-H & - & - & - & 270 & 220 & 410 & 10 & 52 & 70 & 25 & 1.0 \\
ISQG-L & - & - & - & 60 & 50 & 200 & 1.5 & 21 & 20 & 2 & 0.15 \\
\hline
\end{tabular}

Concentrations are in italics if significantly exceeding ISQG-low, or bold italics if significantly exceeding ISQG-high sediment quality guidelines (ANZECC 2000) 

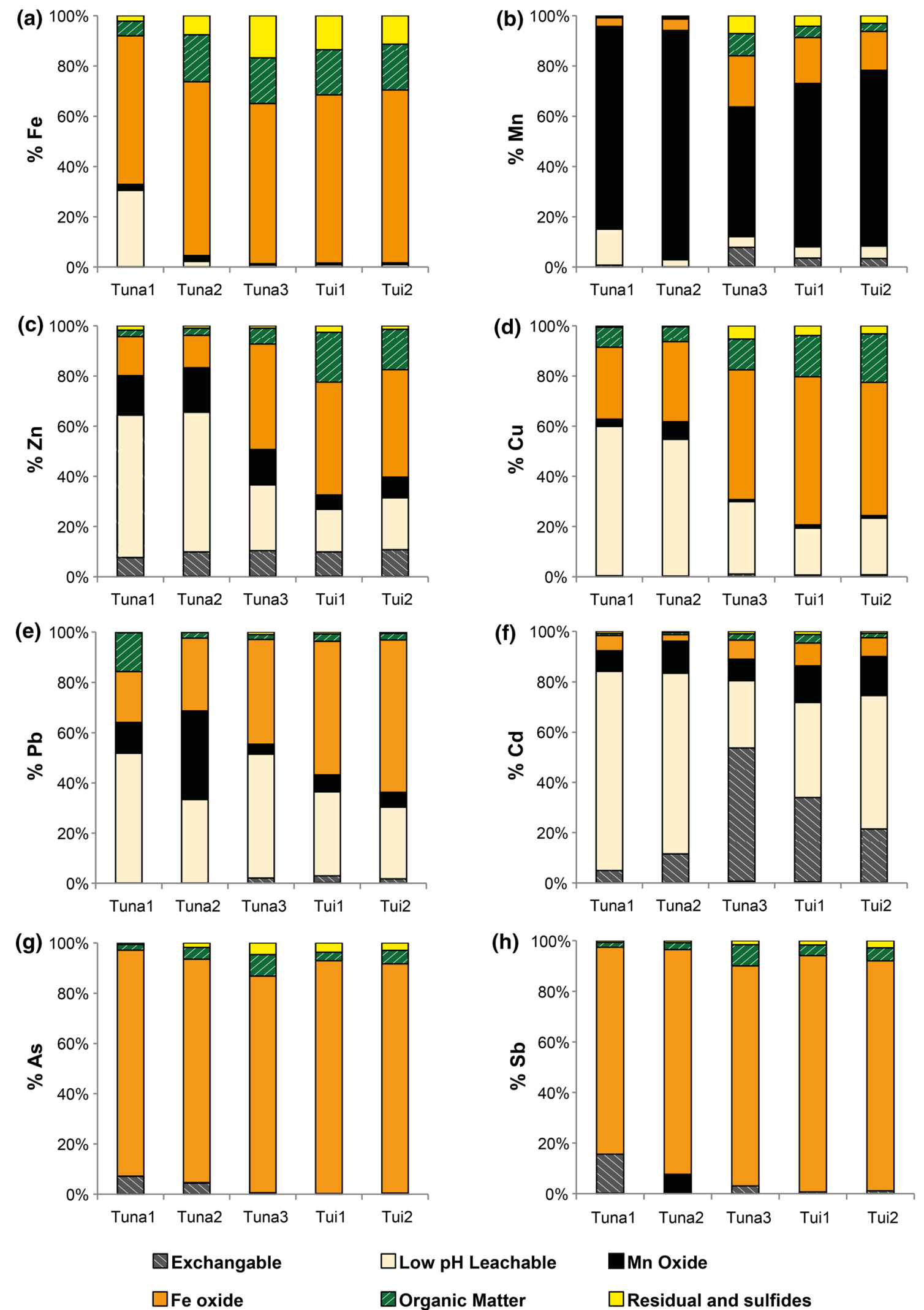

\section{$\square$ Low pH Leachable} ๑Organic Matter

Fig. 5 The percentage of elements extracted from each fraction during the sequential extraction process for sediments in the upper Tunakohoia and Tui stream catchments 

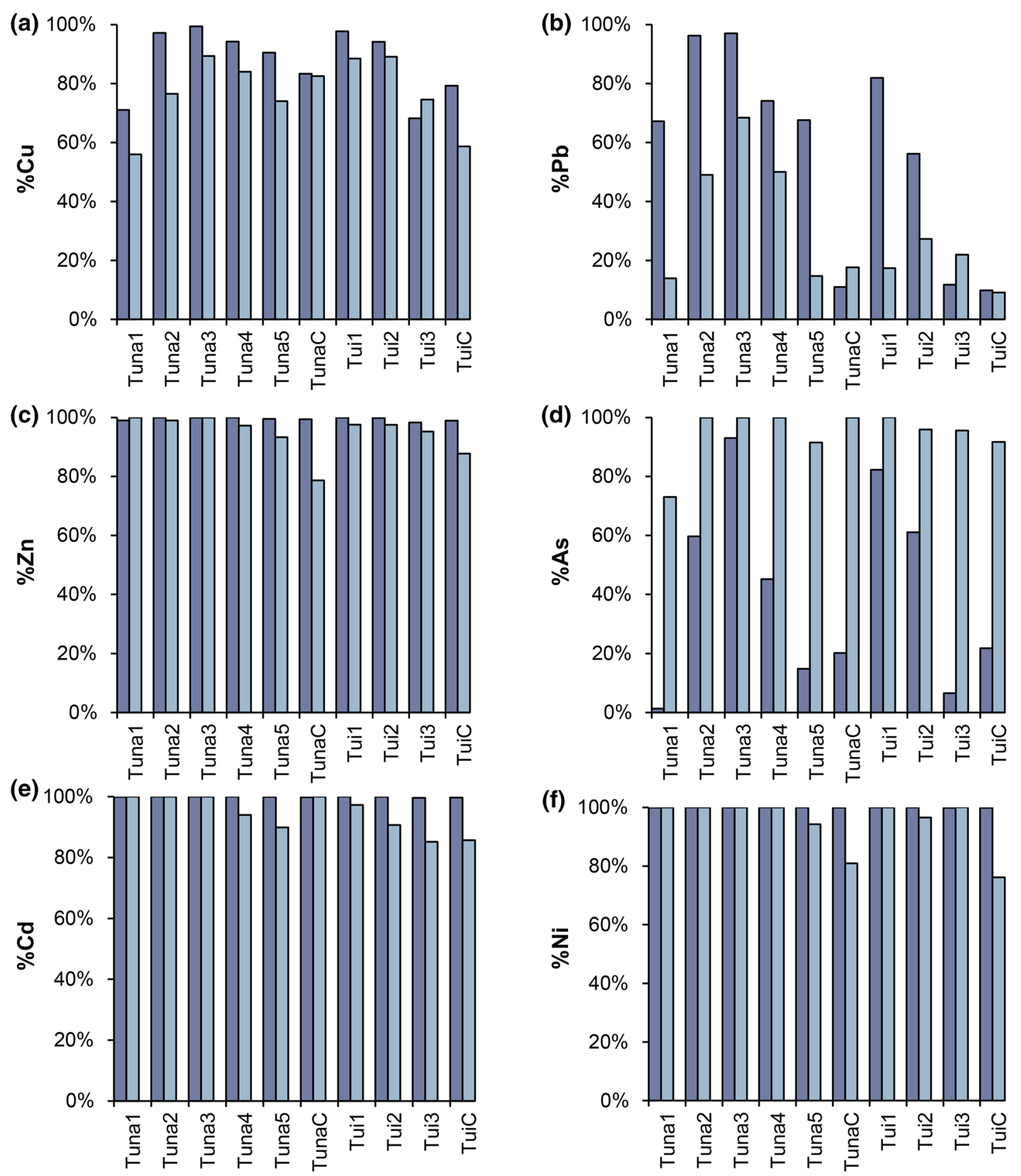

Modelled dissolved

$\square$ Measured dissolved

Fig. 6 The modelled percentage of dissolved trace element in the water column, after adsorption onto available freshly-formed HFO, compared to the measured percentage of dissolved trace element at each site

observed for $\mathrm{Zn}, \mathrm{Cu}, \mathrm{Pb}$, and $\mathrm{Cd}$, but associations for $\mathrm{As}$ and $\mathrm{Sb}$ were more exclusively associated with Fe-oxides. The association of $\mathrm{Fe}, \mathrm{Cu}$, and $\mathrm{Pb}$ was confirmed by SEM elemental mapping while evidence of a $\mathrm{Mn}-\mathrm{Zn}$ association was also seen. No discrete carbonate minerals were observed by SEM. Additionally, although only a small portion of trace elements in the sediment are currently "exchangeable", and therefore readily released in a bioavailable form, the sediment is acting as a reservoir for large quantities of trace elements, which could be released should the geochemical conditions ( $\mathrm{pH}$ or redox) change (Fairgray and WebsterBrown 2017). 


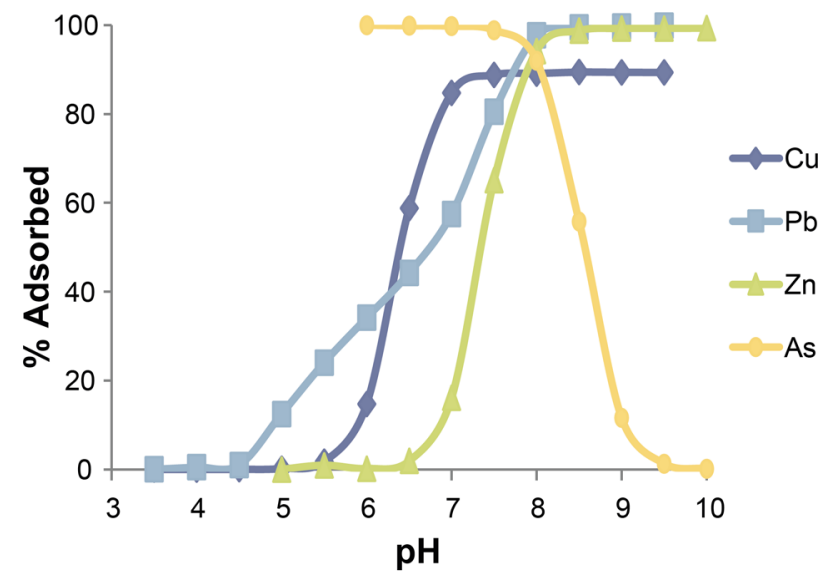

Fig. 7 Adsorption edges for $\mathrm{Cu}, \mathrm{Pb}, \mathrm{Zn}$, and As onto $\mathrm{HFO}$, under the following conditions: temperature $13.7{ }^{\circ} \mathrm{C}$ (Tuna 1), element concentration of $0.01 \mathrm{mg} / \mathrm{L}$ with no competing ions and HFO concentration of $355 \mathrm{mg} / \mathrm{L}$ (Tuna1)

It was reasoned that the trace elements extracted in step three of the sequential extraction process included elements that were released at $\mathrm{pH} 4.5$ [and may also include the dissolution of Fe- and Mn- (oxy)hydroxides] but were not strictly associated with carbonate minerals. This is why step three of the sequential extraction was renamed "low $\mathrm{pH}$ leachable," as opposed to "bound to carbonates," per Leleyter and Probst (1999).

\section{Modelling of Dissolved Trace Element Speciation}

PHREEQC was used to assess the toxicity of trace elements to aquatic life by determining the proportion of the element present as the free ion in a similar method to Waters and Webster-Brown (2013). This predicted that most of the dissolved $\mathrm{Zn}$ and $\mathrm{Cd}$ would be present as free ion and therefore toxic to aquatic life, while the free ion $\mathrm{Cu}$ concentration would be below aquatic protection guidelines. This was supported by ecological data showing that taxa richness is reduced at sites with high $\mathrm{Zn}^{2+}$ and $\mathrm{Cd}^{2+}$ concentrations (Fairgray et al. 2016), indicating that PHREEQC could be reliably used to predict the toxicity of $\mathrm{Zn}$ and $\mathrm{Cd}$ in these environments.

\section{Modelling of Trace Element Speciation in Sediment}

PHREEQC has previously been used extensively to understand mine remediation processes and predict efficacy (Bäckström and Sartz 2011; Rötting et al. 2008; Watten et al. 2005). The ability of a geochemical program to predict the precipitation and dissolution behavior of trace elements has been tested by comparing observed sediment characteristics, with predictions based on processes that could control trace element concentrations and mobility in this catchment system. PHREEQC predicted the precipitation of Fe, Mn, and Al oxides, but no trace element bearing minerals under the current water quality conditions. This is consistent with the lack of trace element minerals phases, other than very minor residual primary $\mathrm{ZnS}$ (sphalerite) in the sediments. This also supports the conclusion that the $\mathrm{Pb}, \mathrm{Cu}, \mathrm{Zn}$, and $\mathrm{Cd}$ extracted in step three of the sequential extraction were not actually associated with carbonate minerals. PHREEQC also indicated that increasing $\mathrm{pH}$ by the addition of more calcite would not significantly change this scenario for Tunakohoia Stream. In Tui Stream, Zn oxide and Mn carbonate precipitation may occur if calcite addition can be used to achieve a high enough $\mathrm{pH}(>8.0)$. Enhanced Fe precipitation could be expected in both catchments. Secondary mineral precipitation is therefore not significantly reducing dissolved trace element concentrations except by adsorption onto the freshly formed secondary Fe, Mn, and Al oxides.

Our results showed that PHREEQC could be used to predict adsorption of trace elements onto HFO by surface complexation, indicating that this was likely an important removal mechanism for $\mathrm{Cu}, \mathrm{Pb}$, and $\mathrm{As}$, but less so for $\mathrm{Zn}, \mathrm{Cd}$, or $\mathrm{Ni}$. However, removal of $\mathrm{Pb}$ (and to a lesser extent $\mathrm{Cu}$ ) was underestimated and As removal was overestimated; using $<5 \%$ of the available HFO better simulated the actual amount of adsorption. This indicates that for $\mathrm{Cu}$ and $\mathrm{Pb}$, adsorption to $\mathrm{HFO}$ is not the only process binding these metals to the sediment, particularly where HFO concentrations were lower, at the control sites and in the lower reaches of the catchments.

The precipitation of Mn oxides was predicted to be currently occurring in the streams, despite the fact that particulate $\mathrm{Mn}$ concentrations (particulate $\mathrm{Mn}=$ total acid soluble Mn-dissolved Mn) in the water samples collected were low. However, moderate proportions of $\mathrm{Mn}, \mathrm{Pb}$, and $\mathrm{Zn}$ were sequentially extracted from the sediment in the Mn oxide fraction. This, combined with the strong association between Mn and Zn observed with SEM, supports the presence of Mn oxide phases, perhaps too fine or only in the sediment where Fe oxides can facilitate their formation (Davies and Morgan 1989). It also indicates that adsorption onto and/or co-precipitation with Mn oxides may be an important metal removal process for $\mathrm{Zn}$ and $\mathrm{Pb}$. However, formation of Mn oxides and attenuation of trace elements to Mn oxides is likely to be of less overall importance than formation of and adsorption to Fe (oxy) hydroxides, given their relative abundance.

PHREEQC reliably predicted the formation of secondary $\mathrm{Fe}$ and $\mathrm{Mn}$ oxide phases and the adsorption of $\mathrm{Zn}, \mathrm{Cd}$, and $\mathrm{Ni}$, and to a lesser extent $\mathrm{Cu}$, onto HFO. It under and overestimated the adsorption of $\mathrm{Pb}$ and $\mathrm{As}$, respectively. We note that a significant limitation of PHREEQC is that 

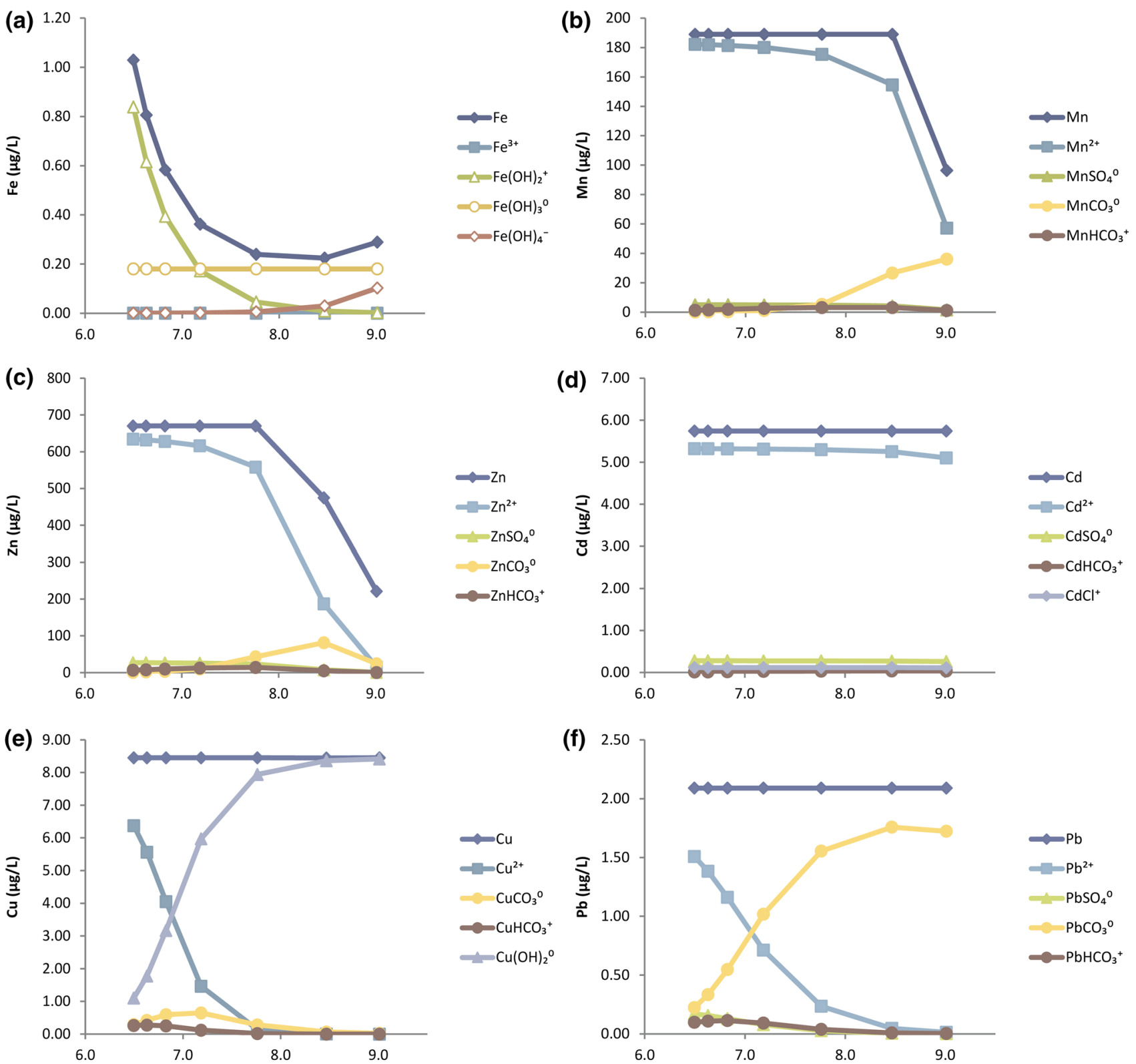

Fig. 8 Modelled changes in dissolved element speciation when a water from Tui 1 (2007 chemistry; Sharplin 2008) is mixed with calcite, simulating the remediation works carried out at the mine site between 2010 and 2013

it assumes that the system is at thermodynamic equilibrium. This may not always be the case when fast moving mine drainage streams allow little time for sediment-water interactions to take place. However, if water and sediment chemistry are constant with time, such programs can still provide useful predictions of AMD effects on impacted aquatic environments. In the case of the Tui Mine, for example, modelling of geochemical processes indicates that further mine remediation through calcite addition alone is unlikely to be more effective.

\section{Conclusions}

The extent to which mine site restoration has been achieved has been evaluated by geochemical assessments, measurements, and modelling. Mineral precipitate formation is identified as an important metal removal process for $\mathrm{Fe}$ and $\mathrm{Mn}$. Adsorption onto these precipitates and the formation of complexes has reduced $\mathrm{Cu}, \mathrm{Pb}$, and As concentrations, such that these elements now meet aquatic health guideline values. 

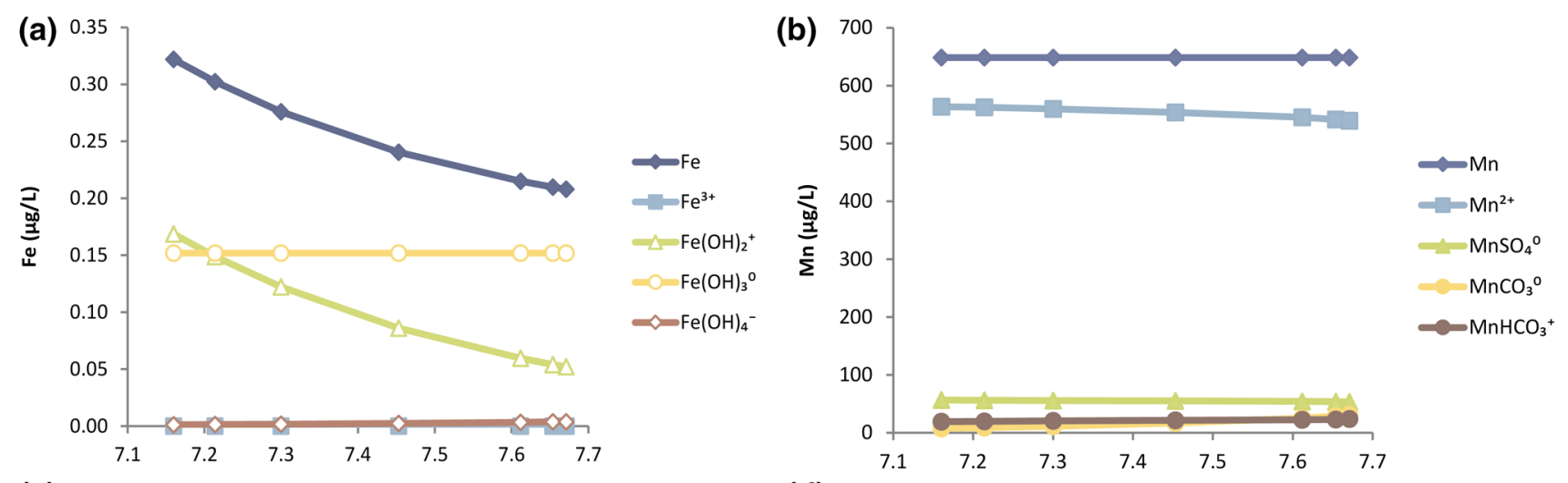

(c)

(d)
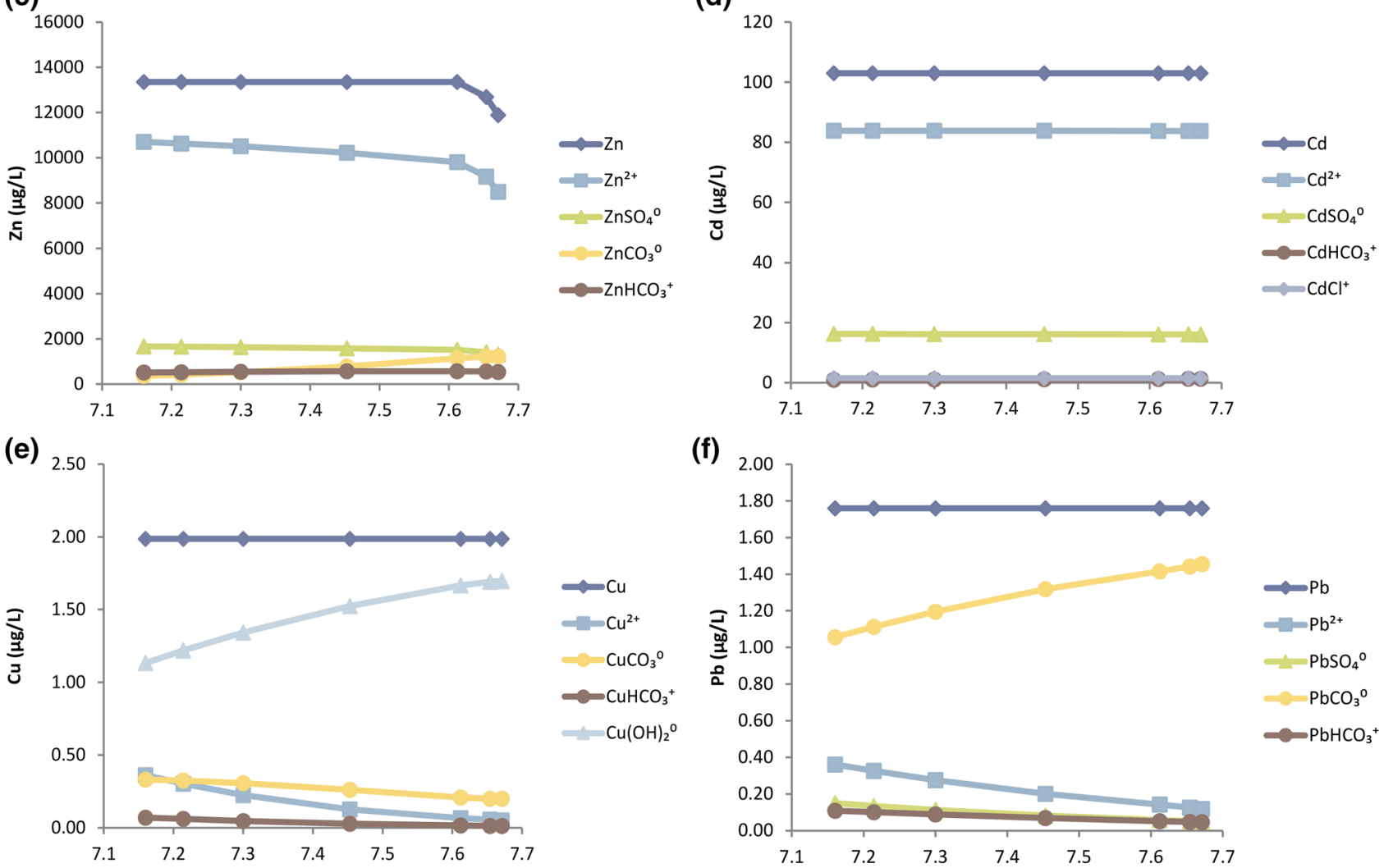

Fig. 9 Modelled changes in dissolved element speciation when a water from Tuna 1 (2007 chemistry; Sharplin 2008) is mixed with calcite, simulating the remediation works carried out at the mine site between 2010 and 2013

Neither the formation of mineral precipitates nor sorption to freshly formed mineral precipitates has reduced $\mathrm{Zn}$ and $\mathrm{Cd}$ concentrations enough to meet water quality guidelines. Modelling has shown that this is unlikely to be achieved by more of the same rehabilitation methods [i.e. addition of limestone $\left.\left[\mathrm{CaCO}_{3}\right]\right]$.

PHREEQC proved to be reliable for predicting $\mathrm{Cu}, \mathrm{Zn}$, and $\mathrm{Cd}$ concentrations when HFO was determined by the difference between acid soluble and dissolved Fe concentrations, but was less reliable for $\mathrm{As}$ and $\mathrm{Pb}$. Modelling also indicated where further characterization of the water and the sediment binding phases was required.

Acknowledgements The authors thank: the Ministry of Business, Innovation and Employment (MBIE) for funding this research (CRLE 1403 contract); the laboratory staff at Lincoln University (John Revell, Roger Cresswell, and Lynne Clucas) and the University of Canterbury (Rob Stainthorpe) who carried out sample analysis; Mike Flaws (UC) for assistance with SEM imaging; Phil White (Panda Geosciences) for XRD analysis; Prof. Jon Harding, Justin Pomeranz, Dr. Kevin Simon, and Rose Gregersen who accompanied the authors during field work and carried out sampling and identification of macroinvertebrate 
samples; the Waikato Regional Council for access to the site; and the Iwi Advisory Group for their cultural guidance.

Open Access This article is distributed under the terms of the Creative Commons Attribution 4.0 International License (http://creativeco mmons.org/licenses/by/4.0/), which permits unrestricted use, distribution, and reproduction in any medium, provided you give appropriate credit to the original author(s) and the source, provide a link to the Creative Commons license, and indicate if changes were made.

\section{References}

Akcil A, Koldas S (2006) Acid mine drainage (AMD): causes, treatment and case studies. J Clean Prod 14:1139-1145

ANZECC (2000) Australian and New Zealand guidelines for freshwater and marine water quality. Australian and New Zealand Environment Conservation Council, Canberra

Bäckström M, Sartz L (2011) Mixing of acid rock drainage with alkaline ash leachates-fate and immobilisation of trace elements. Water Air Soil Pollut 222:377-389

Bacon JR, Davidson CM (2008) Is there a future for sequential chemical extraction? Analyst 133:25-46

Banks D, Younger PL, Arnesen RT, Iversen ER, Banks SB (1997) Mine-water chemistry: the good, the bad and the ugly. Environ Geol 32:157-174

Blowes DW, Ptacek CJ, Jambor JL, Weisener CG (2003) The geochemistry of acid mine drainage. In: Lollar BS, Holland HD, Turekian KK (eds) Treatise on geochemistry, vol 9. Elsevier, New York, pp 149-204

Bradshaw AD, Chadwick MJ (1980) The restoration of land: the ecology and reclamation of derelict and degraded land. University of California Press, Berkeley

Campbell PGC (1995) Interactions between trace metals and aquatic organisms: a critique of the free-ion activity model. In: Tessier A, Turner DR (eds) Metal speciation and bioavailability in aquatic systems. Wiley, New York, pp 45-102

Cooke JA, Johnson MS (2002) Ecological restoration of land with particular reference to the mining of metals and industrial minerals: a review of theory and practice. Environ Rev 10:41-71

Dale JG, Stegemeier JP, Kim CS (2015) Aggregation of nanoscale iron oxyhydroxides and corresponding effects on metal uptake, retention, and speciation: I. Ionic-strength and $\mathrm{pH}$. Geochim Cosmochim Acta 148:100-112

Davies SHR, Morgan JJ (1989) Manganese(II) oxidation kinetics on metal oxide surfaces. J Colloid Interface Sci 129:63-77

Dzomback DA, Morel FMM (1990) Surface complexation modeling: hydrous ferric oxide. Wiley, New York City

Fairgray M, Webster-Brown J (2017) Release of toxic trace elements from contaminated stream sediment at Tui Mine Te Aroha, New Zealand. In: Proceedings of AusIMM New Zealand Branch Annual Conference, Christchurch, New Zealand

Fairgray M, Webster-Brown J, Harding J, Waters AS (2016) Geochemical modelling of metal toxicity in the Tui Mine catchment, Te Aroha, NZ. In: Proceedings of AusIMM New Zealand Branch Annual Conference, Wellington, New Zealand, pp 100-108

Gholinejad M, Karimi B, Mansouri F (2014) Synthesis and characterization of magnetic copper ferrite nanoparticles and their catalytic performance in one-pot odorless carbon-sulfur bond formation reactions. J Mol Catal A Chem 386:20-27

Harvey SA, Webster-Brown JG (2003) Environmentally and publicly acceptable options for remediation at Tui Mine site, Te Aroha. In: Proceedings of AusIMM New Zealand Branch Annual Conference Greymouth, New Zealand
Hendy CH (1981) The Tui Mine-after the miners have left. NZ Environ 29:17-19

Johnson DB, Hallberg KB (2005) Acid mine drainage remediation options: a review. Sci Total Environ 338:3-14

Kolta GA, El-Tawil SZ, Ibrahim AA, Felix NS (1981) Kinetics and mechanism of copper ferrite formation. Thermochim Acta 43:279-287

Leleyter L, Probst J-L (1999) A new sequential extraction procedure for the speciation of particulate trace elements in river sediments. Int J Environ Anal Chem 73:109-128

Long ER, Macdonald DD, Smith SL, Calder FD (1995) Incidence of adverse biological effects within ranges of chemical concentrations in marine and estuarine sediments. Environ Manag 19:81-97

Lottermoser BG (2003) Mine wastes. Springer, Germany

Morrell WJ (1997) An assessment of the revegetation potential of basemetal tailings from the Tui Mine, Te Aroha, New Zealand. PhD Thesis, Massey University, New Zealand

Nordstrom DK, Alpers CN (1999) Geochemistry of acid mine waters. In: Plumlee GS, Logsdon MJ (eds) Reviews in economic geology, vol 6. Society of Economic Geologists, Littleton, pp 133-160

Pang L (1995) Contamination of groundwater in the Te Aroha area by heavy metals from an abandoned mine. J Hydrol NZ 33(1):17-34

Parkhurst DL, Appelo CAJ (2013) Description of input and examples for PHREEQC. Version 3-A computer program for speciation, batch-reaction, one-dimensional transport, and inverse geochemical calculations. US Geological Survey Techniques and Methods, Book 6. USGS, Reston, WV, USA

Rötting TS, Thomas RC, Ayora C, Carrera J (2008) Passive treatment of acid mine drainage with high metal concentrations using dispersed alkaline substrate. J Environ Qual 37:1741-1751

Sabti H, Hossain MM, Brooks RR, Stewart RB (2000) The current environmental impact of base-metal mining at the Tui Mine, Te Aroha, New Zealand. J Roy Soc New Zeal 30:197-207

Salvarredy-Aranguren MM, Probst A, Roulet M, Isaure M-P (2008) Contamination of surface waters by mining wastes in the Milluni Valley (Cordillera Real, Bolivia): mineralogical and hydrological influences. Appl Geochem 23:1299-1324

Sharplin REP (2008) Environmental geochemistry after partial site remediation at Tui Mine, New Zealand. MSc Thesis, University of Auckland, NZ

Stark JD, Boothroyd IK, Harding JS, Maxted JR, Scarsbrook MR (2001) Protocols for sampling macroinvertebrates in wadeable streams. New Zealand Macroinvertebrate Working Group Report No. 1. Ministry for the Environment, Wellington, NZ

Tay KA (1980) Geochemistry and environmental impact of the discharge of heavy metals from the Tui Mine and its tailings. MSc Thesis, University of Waikato, NZ

Warrender R, Pearce NJG, Perkins WT, Florence KM, Brown AR, Sapsford DJ, Bowell RJ, Dey M (2011) field trials of low-cost reactive media for the passive treatment of circum-neutral metal mine drainage in mid-Wales, UK. Mine Water Environ 30:82-89

Waters AS, Webster-Brown JG (2013) Assessing aluminium toxicity in streams affected by acid mine drainage. Water Sci Technol 67:1764-1772

Watten BJ, Sibrell PL, Schwartz MF (2005) Acid neutralization within limestone sand reactors receiving coal mine drainage. Environ Pollut 137:295-304

Watzlaf GR, Schroeder KT, Kleinmann RL, Kairies CL, Nairn RW (2004) The Passive Treatment of Coal Mine Drainage. US Dept of Energy National Energy Technology Laboratory, DOE/ NETL-2004/1202

Webster JG (1995) Chemical processes affecting trace metal transport in the Waihou river and estuary, New Zealand. N Z J Mar Fresh 29:539-553 
Webster-Brown JG, Lane V (2005) Modeling seasonal arsenic behavior in the Waikato River, New Zealand, vol 915. ACS Symp Series. Oxford University Press, Oxford, pp 253-266

Winterbourn MJ, Gregson KLD, Dolphin CH (2006) Guide to the aquatic insects of New Zealand, 4th edn. Bulletin of the Entomological Society of New Zealand 14
Wodzicki A, Weissberg BG (1970) Structural control of base metal mineralisation at the Tui Mine, Te Aroha, New Zealand. N Z J Geol Geophys 13:610-630

Ziemkiewicz PF, Skousen JG, Brant DL, Sterner PL, Lovett RJ (1997) Acid mine drainage treatment with armored limestone in open limestone channels. J Environ Qual 26:1017-1024 